\title{
The Role of Genetic Polymorphisms in the Chemokine and Their Receptors and Cytokines in the Human Immunodeficiency Virus Type 1 (HIV-1) Infection
}

\author{
Edna Maria Vissoci Reiche, Marla Karine Amarante and \\ Maria Angelica Ehara Watanabe \\ State University of Londrina \\ Brazil
}

\section{Introduction}

The natural history and pathogenic processes of human immunodeficiency virus type 1 (HIV1) infection are complex and variable, and depend on many viral and host factors and their interactions (Pantaleo et al., 1997). Individuals are not equal susceptible to the infection and have differences in their viral set points, rates of decline of $\mathrm{CD} 4^{+} \mathrm{T}$ cells, levels of viremia, emergence of citotoxic T lymphocyte (CTL) escape mutants, and development of opportunistic infections resulting in varying incubation periods of the virus (Kaur \& Mehra, 2009). HIV-1 infected individuals present different rates of disease progression; while a majority of individual progress to acquired immunodeficiency syndrome (AIDS) after the infection, most of them can be turned aviremic even the absence of antiretroviral therapy (ARV) up to ten years and are called typical progressors. Most importantly, 5\% to $10 \%$ of persistently infected individuals show no signs of disease progression for over 12 years and remain asymptomatic and aviremic and are classified as long term nonprogressors (LTNPs). On the other hand, rapid progressors are individuals that rapidly progress to AIDS within four years after primary HIV-1 infection and some individuals have been known to progress to AIDS and death within a year after primary infection (Fauci et al., 1996; Rosenberg \& Fauci, 1991).

Genetic factors may be one of the host factors responsible for the susceptibility to infection and disease progression. However, no single gene or polymorphism is likely to be responsible for these effects. Brass et al. (2008) have reported that HIV-1 uses at least 250 host-derived dependency factors for gaining entry into target cells and completing its life cycle. Hence, multiple genetic factors are expected to be involved in susceptibility, disease pathogenesis, and progression following HIV-1 infection. Some of these genes that have been established with HIV/AIDS conclusively involve are: (1) genes influencing viral entry by altering the expression on cell surface the levels of chemokine receptors and their ligands as well cytokines (Seisdedos \& Parmentier, 2006; Reiche et al., 2007); (2) genes involved in anti-HIV immune response including the antiviral Apolipoprotein B mRNA-editing enzyme, catalytic polypeptide-like 3G (APOBEC3G) gene family on chromosome 22q13 (An et al., 2009); the virus restriction factor Tripartite Interaction Motif $5 \alpha$ (TRIM5 $\alpha$ ) on 
chromosome 11p15; (3) the human leukocyte antigens (HLA) polymorphic loci and their associated genes including HCP5, RNF39, and ZNRD1 on the short arm of human chromosome 6; (4) Dendritic Cell Specific Intracellular adhesion molecule-3-Grabbing Nonintegrin (DC-SIGN) on chromosome 19q13; (5) interferon regulatory factor 1; (6) killer cell immunoglobulin-like receptor (KIR) KIR3DSI on chromosome 19q13; and (7) Ly6 family of G [glycosylphosphatidylinositol (GPI)-anchored proteins] (Kaur \& Mehra, 2009).

This chapter reviews the most important genetic polymorphisms already described in the chemokine, cytokine and their receptors, and their role on the host susceptibility or resistance to HIV-1 infection, on the clinical course of the disease and on the response to the ARV. For this purpose, in vitro and in vivo studies for inclusion were identified by a systematic search through PubMed for English-language literature, included original and review articles published up to 2010. These data could contribute to identify some genetic biomarkers for infection, transmission, disease progression or ARV therapeutic failure.

\section{Genetic polymorphisms in $\mathrm{CC}$ chemokines and their receptors}

Chemokines are low-molecular-weight potent chemoattractants produced by a variety of cell types that include T cells, macrophages, natural killer (NK) cells, B cells, fibroblasts, and mast cells. These are involved in cell trafficking and immunomodulation of inflammation and immune responses. The chemokines are subdivided into $\mathrm{CC}, \mathrm{CXC}$, and $\mathrm{CX}_{3} \mathrm{C}$ subfamilies, according to the number of cysteine residues in the molecule. Members of CC chemokines are CCL3 [macrophage inflammatory protein-1 (MIP-1 $\alpha$ )], CCL4 [macrophage inflammatory protein $1 \beta$ (MIP-1 $\beta)$ ], and CCL5 [regulated upon activation normally Texpressed (RANTES)]. They are natural ligands for CC chemokine receptor R 5 (CCR5). One member of CXC chemokines is CXC ligand 12 (CXCL12), previously named stromal cellderived factor 1 (SDF1), a natural ligand for CXC receptor 4 (CXCR4). In certain instances, the chemokine receptors serve as entry portals for pathogens to gain entry into target cells and establish infection. Based on cell tropism, HIV-1 isolates are classified into two main groups. The vast majority of primary HIV-1 isolates is, predominantly, tropic for CCR5 and gradually tends to become CXCR4 tropic during late infection. All non-syncytium-inducing (NSI) strains of HIV-1 require CCR5 to gain entry into target cells and are also named R5 strains, while the syncytium-inducing (SI) strains use CXCR4 to enter into host cells and are also named as X4 strains (Berger et al., 1999). Functional genetic polymorphisms are known to occur in these proteins that affect their levels of expression and therefore might modulate their molecular interactions.

\subsection{CCL3, CCL4 and CCL18}

The genes coding for CCL3 (MIP-1 $\alpha$ ), CCL4 (MIP-1 $\beta)$, and CCL18 [also referred to as small inducible cytokine subfamily A member 18 or pulmonary and activation-regulated chemokine (PARC)], are clustered together within a 47-kb region on chromosome 17q12. These are potent chemokines produced by macrophages, NK cells, fibroblasts, and T cells. Of these, CCL2, CCL3 and CCL4 are natural ligands for the primary HIV-1 coreceptor CCR5, and their genetic polymorphisms have been implicated in HIV-1 acquisition and disease progression, although these associations are complicated because of strong linkage disequilibrium between them (Modi et al., 2006). 


\subsection{CCL5}

The CCL5 (RANTES) gene is located on chromosome 17 which encodes a chemokine ligand for CCR1, CCR3, and CCR5. It suppresses infection for R5 strains of HIV-1 by blocking CCR5 (Paxton et al., 1996; Arenzana-Seisdedos et al., 1996). Some polymorphisms in CCL5 promoter region protect HIV-1 infected subjects against disease progression as a result of increased CCL5 synthesis (Liu et al., 1999; Wichukchinda et al., 2006). Three single nucleotide polymorphisms (SNPs) in this gene $(-28 C \rightarrow G,-403 G \rightarrow A$, and in 1.1C) were reported for their roles in progression to AIDS in HIV-1 infected individuals. The variant alleles $-28 \mathrm{G}$ and $-403 \mathrm{~A}$ were found to be associated with delayed progression to AIDS in Japanese population by increasing levels of CCL5 transcription and by reducing rates of $\mathrm{CD}^{+}{ }^{+} \mathrm{T}$-cell depletion (Liu et al., 1999). Other study also suggested that polymorphisms in the CCL5 promoter gene can influence the risks for HIV-1 infection and disease progression by increasing the CCL5 levels (McDermott et al., 2000; Koning et al., 2003). In the other hand, the SNP In 1.1C, nested within an intronic regulatory sequence element, accelerated the progression to AIDS in African Americans and European Americans by downregulating the CCL5 gene transcription (An et al., 2002). Study by Wichukchinda et al. (2006) demonstrated the mutation's protective effect by comparing disease progression in seroconverters carrying either the CCL5-28G or the CCL5 In.1.1C polymorphism. Individuals carrying the CCL5 In.1.1C allele progressed significantly faster to AIDS compared with those carrying the CCL5 - 28G allele, along with those HIV-1-infected subjects without these mutations.

\subsection{CCL3L1, CCL4L1}

Human CC chemokine ligand 3 like 1 gene (CCL3L1) is a natural ligand of HIV-1 coreceptor CCR5 and a potent HIV-1 supressive chemokine that can physically block the entry of HIV1. The CCL3L1 gene is located on human chromosome $17 \mathrm{q} 11.2$ and shares $96.0 \%$ amino acid homology with CCL3. The copy number of the CCL3L1 gene varies among different individuals and populations groups (Kaur \& Mehra, 2009). CCL3L1 and CCL4L1 genes harbor several SNPs and hotspots for duplication, resulting in distinct haplotypes and copy number variations, respectively, in different individuals (Modi et al., 2006). The copy numbers are highest in Africans, followed by Asians, Amerindians Central and South Asians, Middle East individuals and Europeans. Variations in a copy numbers of CCL3L1 alter the expression of this potent CCR5 ligand and might influence the entry of HIV-1 into host cells. Copy number variations in CCL3L1 have been associated with susceptibility to HIV-1 infection (Gonzalez et al., 2005). However, the results are contradictory in different populations. A study carried out in the Japanese population (Nakajima et al., 2007) has shown that HIV-1 infected individuals have lower copy number than healthy controls. On the contrary, studies in North Indian population showed that the copy number variation in CCL3L1 gene has no effect on acquisition in HIV-1 infected individuals compared with healthy controls (Nakajima et al., 2008). Another study showed an association of CCR559029 A/G and CCL3L1 copy number polymorphism with HIV-1 transmission and progression among HIV-1 seropositive and repeatedly sexually exposed HIV-1 seronegative North Indians individuals, suggesting that these polymorphisms appeared to have synergistic or interactive effects and are expected to be involved in the host innate resistance to HIV-1 infection (Rathore et al., 2009). 


\subsection{CCR5}

CCR5 is normally expressed at very low levels on the surface of naïve CD4 $4^{+} \mathrm{T}$ cells and at higher levels in activated $\mathrm{CD}^{+}$memory $\mathrm{T}$ cells as well as in monocytes and macrophages (Potter et al., 2007). Multiple polymorphic variations have been described in the CCR5 gene that is located on chromosome $3 p 21$. CCR5- $\Delta 32$ polymorphism is the first and most well characterized host restriction allele associated with AIDS. This natural knockout deletion of 32 base-pair creates a premature stop codon resulting in truncated protein product, a shortened protein which remains intracellular and fails to reach the cell surface in individuals homozygous for the variant. The first study described a frequency of approximately 0.100 for the null-mutant allele of the CCR5 gene in the Caucasian population. Heterozygotes for the allele have reduced levels of quantifiable CCR5 receptors in the cell surface and were present at similar frequencies among infected and uninfected cohort controls. Among HIV-1 infected homosexual cohorts, heterozygosity correlated well with decreased disease progression. However, no correlation was apparent among the haemophilic population (Dean et al., 1996).

A second study identified the same mutant allele of CCR5 in two homozygous individuals who had been repeatedly exposed to the HIV-1 but remained uninfected (Liu et al., 1997). The results also showed that the mutation makes the CCR5 protein incapable of mediating infection by HIV-1 in vitro. A third study suggested that heterozygosity also provides some protection from HIV-1 infection (Samson et al., 1996) and the discrepancy regarding the protection from HIV-1 infection was most likely due to the difference between the populations evaluated. The first study (Dean et al., 1996) compared large and matched cohorts of individuals, whereas the third (Samson et al., 1996) examined only non-cohort population matched by geographical location and the use of a French surname.

Even though homozygosity for the CCR5- $\Delta 32$ results in near-total protection for the HIV-1 infection, subjects can still be infected with T-tropic or SI strains of the virus, which use the CXCR4 coreceptor for cell entry (Dean et al., 1996; Samson et al., 1996; Zimmerman et al., 1997; O’Brien et al., 1997; Theodorou et al., 1997). Studies of HIV-1 infected homozygous for the CCR5- $\triangle 32$ mutation have been reported, but are rare (O'Brien et al., 1997; Theodorou et al., 1997; Balotta et al., 1997; Biti et al., 1997), probably due to a T-tropic virus, strain which only uses CXCR4 as coreceptor for cell entry.

Heterozygosity for the CCR5- $\Delta 32$ is significantly higher in cohorts of HIV-1 infected LTNPs compared to HIV-1 infected typical progressors (Cohen et al., 1997; Zimmerman et al., 1997; Eugen-Olsen et al., 1997). Although the heterozygosity was not related to the complete protection against HIV-1 infection (Dean et al., 1996; Samson et al., 1996), it may confer partial protection against disease progression or death in HIV-1 infected individuals (Zimmerman et al., 1997; Smith et al., 1997; Martin et al., 1998; de Roda et al., 1997; Meyer et al., 1999; Ionnadis et al., 1998). Presumably, heterozygosity limits the number of coreceptors available for HIV-1 binding. Indeed, CCR5 density of the surface of the CD4+ $\mathrm{T}$ cell has been correlated with viral load in persons with untreated HIV-1 infection (Reynes et al., 2000). Studies incorporating viral phenotype have suggested that the protective effect of CCR5- $\Delta 32$ heterozygosity against disease progression is lost when the infection virus is T-tropic (Michael et al., 1997).

An international meta-analysis showed that HIV-1 infected subjects heterozygous for the CCR5- $\triangle 32$ displayed lower HIV-1 RNA level than wild type patients. This result appears to be supported by the simple explanation that the fewer available CCR5 portals on cells of 
CCR5- $\triangle 32$ delay HIV-1 replication and the virus-mediated destruction of the CD4 ${ }^{+} / \mathrm{CCR} 5^{+}$ T-cell lymphocyte population (Ioannidis et al., 2001). The observation that this naturallyoccurring genetic mutation can slow or delay the onset of AIDS in patient populations was the basis of therapeutic interventions targeting the interaction between the virus and the coreceptor CCR5.

Several other mutations in the coding region of the CCR5 gene have been identified (Carrington et al., 1997). Ten common SNPs within the 1,000 base-pairs region upstream of CCR5-coding exons that exhibit promoter and regulatory activity have been described, possibly affecting the levels of CCR5 expression (Carrington et al., 1999; Martin et al., 1998; Kostrikis et al., 1998; Quillent et al., 1998; Piacentini et al., 2009). These polymorphisms are identified as CCR5P1 to CCR5P10 and the most common of them are CCR5P1 and CCR5P4 (Chatterjee, 2010).

The CCR5P1/P1 promoter allele was the first genetic variant in the CCR5 promoter to be associated with rapid progression of AIDS, although variants of other genes have been described more recently to be AIDS-accelerating (Carrington et al., 1997; Faure et al., 2000). The hypothesis that the genetic effect is mediated by an increase in available CCR5 portals is also supported by the epidemiologic pattern. The strongest acceleration mediated by the CCR5P1/P1 genotype occurs in the first five years of infection, a period when R5 (NSI) virus strains predominate in $90.0-95.0 \%$ of patients (Schuitemaker et al., 1992).

The A/G polymorphism at base-pair 59029 in the CCR5 promoter was identified and appears to affect the rate of progression to AIDS in HIV-1 infected homosexuals. The CCR5 59029 G/G genotype appears to be more protective than CCR5 59029 A/A, and this effect may be the result of a reduced CCR5 mRNA production. The A allele exhibits a $50.0 \%$ higher expression of CCR5 in vitro and confers faster disease progression than the G allele (Passam et al., 1999). These results indicated that this site in the CCR5 promoter is important and may be a useful target for treatment of the HIV-1 infection (McDermott et al., 1998).

It is estimated that homozygozity for the CCR5P1/P1 promoter allele was responsible for the development of the disease in $10.0 \%$ to $17.0 \%$ of the patients who developed AIDS within 3.5 years of HIV-1 infection, irrespective of the CCR5- $\Delta 32$ and CCR2-64I (defined in this chapter in the next sections) genotypes. The frequency of this susceptible genotype in the general population is only $7.0 \%$ to $13.0 \%$ (Martin et al., 1998).

Homozygosity for CCR5-59356-T, a polymorphism more frequent in the African-American rather than in Caucasian or Hispanic populations, has been strongly associated with an increased rate of perinatal HIV-1 transmission (Kostrikis et al., 1999). Additionally, the $59353 \mathrm{C}$ allele is found in higher frequency in some progressors compared with LTNPs (Jang et al., 2008).

Complete linkage disequilibrium between CCR5P1 and CCR5-2459A sites and the CCR5P1 haplotype was shown to be associated with rapid progression to AIDS endpoints in both African-American and Caucasians cohorts. This effect was recessive in Caucasians and dominant in African-Americans, probably due to the presence of modulating genes or as yet unidentified polymorphisms with different frequencies among the racial groups (An et al., 2000). This same study described that both CCR5P1 homozygous and heterozygous AfricanAmericans showed a trend towards more rapid progression to AIDS endpoints. Similar to the recessive effect of the CCR5P1 allele in Caucasians, which was strongest in the first 4-6 years following seroconversion, the dominant effect of the CCR5P1 allele in AfricanAmericans was also evident in the first 4 years. This result is consistent with both the 
function of CCR5 as the coreceptor for early transmissible M-tropic HIV-1 strains and also with the studies of CCR5- $\triangle 32$ showing an early effect (Dean et al., 1996).

Unlikely the CCR5- $\triangle 32$ mutation which is found only in people of Northern European descent, the CCR5P1 allele has a frequency larger than $40.0 \%$ both in Caucasians, Asians and populations of African descent, suggesting that the CCR5P1 allele may have a more general effect on AIDS pathogenesis worldwide (An et al., 2000).

Another SNP in CCR5 gene is a $\mathrm{T} \rightarrow \mathrm{A}$ substitution (named CCR5-m303A polymorphism) and results in a Threonine to Alanine transition at position 303. It encodes a truncated protein and abolishes the coreceptor activity of CCR5. This polymorphism shows a weak association with delayed progression to AIDS. When is present in heterozygous state with CCR5- $\Delta 32$, produces a phenotype of resistance to HIV-1 in primary isolates in vitro (Quillent et al., 1998).

Based on a unique constellation of additional multisite polymorphisms in CCR5 regulatory 5' region, a number of CCR5 haplotypes have been identified (Gonzalez et al.,1999; Martin et al., 1998). They have been designed based on the nucleotide position in the $5^{\prime}$ untranslated region (UTR) and are referred to as human haplogroups A to G. Of these, HHE has been associated with accelerated disease progression in Caucasians (Gonzalez et al., 1999) and Thais (Nguyen et al., 2004) but not in African Americans. The HHC and HHD haplotypes showed positive association with fast progression to AIDS in African Americans (Kostrikis et al., 1999; Nguyen et al., 2004). In the Indian population, HHE has been implicated with susceptibility to infection and development of AIDS (Kaur et al., 2007). Whether this haplotype also influences disease progression is not clear because long-term follow-up is desirable to reach such a conclusion (Kaur \& Mehra, 2009).

\subsection{CCR2}

Although the HIV-1 virus does not directly use CCR2 for host cell entry, and CCR2 is considered a minor coreceptor for HIV-1 infection, a Valine to Isoleucine substitution at position 64 in the first transmembrane domain of CCR2 (named CCR2-64I, V64I or G190A) has been associated with delayed progression to AIDS (Smith et al., 1997). HIV-1 infected individuals heterozygous or homozygous for this mutation appear to progress to AIDS or death more slowly. However, this mutation results in normal levels of expression of the CCR2 receptor and has not been shown to affect the susceptibility to HIV-1 infection (Smith et al., 1997; Martin et al., 1998; de Roda et al., 1997; Kostrikis et al., 1998; Mummidi et al., 1998; Mulherin et al., 2003).

Even though the change of the Valine to Isoleucine in a position buried in one of the seven transmembrane segments of this receptor could be considered innocuous, the epidemiological effect on AIDS progression was surprising. It has been shown that the CCR2-64I protein product can preferentially dimerizes with the CXCR4 polypeptide, sequestering it in the endoplasmic reticulum, while the CCR2 peptides cannot. Such differential intracellular kinetics between CCR2 allele products and primary HIV-1 coreceptors in vivo could reduce the rate of disease progression by limiting the number of available CXCR4 coreceptors, therefore also reducing indirectly the rate of viral replication (O'Brien and Moore, 2000). However, this effect on disease progression has not confirmed (Michael et al., 1997; Eugen-Olsen et al., 1998).

The distribution of CCR2-64I varies among different ethnic groups. Unlike the CCR5- $\Delta 32$ mutation, which is found primarily in Caucasians, the frequency of the CCR2-64I allele 
varies from $10.0 \%$ to $25.0 \%$ in both African-Americans and Caucasians, and in all other ethnic groups studied. The protective allele A occurs at a population frequency of $15.0 \%-17.0 \%$ in Chinese, $12.0 \%$ in the North Indians (Kaur et al., 2007), and 3.0\%-15.0\% in the South Indian populations (Ramana et al., 2001). Studies of HIV-1 infected commercial sex workers in Nairobi and Kenya, suggested that the presence of the mutation helped to explain slow progression in $21.0 \%$ to $46.0 \%$ of slow progressors (Anzala et al., 1998). The effect of the CCR5- $\Delta 32$ allele on HIV-1 disease progression was also different from the effect of the CCR2 allele. The protection against AIDS provided by CCR5- $\Delta 32$ was continuous during the course of infection, while the protection provided by CCR2-64I was the greatest early in the course of infection (Mulherin et al., 2003).

A meta-analysis study found that in the absence of highly active antiretroviral therapy (HAART), both CCR5- $\triangle 32$ and CCR2-64I carriers progressed to AIDS at a $25.0 \%$ slower rate than individuals who lacked either of these protective alleles. They also progressed more slowly to death, approximately $35.0 \%$ and $25.0 \%$ slower, respectively (Ioannidis et al., 2001). Mabuka et al. (2009) verified that the presence of the CCR2-64I allele was associated with reduced viral load and with protection against early HIV-1 transmission among pregnant women who received short course zidovudine. In Kenya and other African countries, where approximately one quarter of individuals carry the variant allele, understanding this genetic mutation may help explain disparities in transmission risk and rates of disease progression and could contribute to vaccine development and other prevention interventions.

Because the genetic loci for CCR5 and CCR2 are in strong linkage disequilibrium, their combined analysis is greatly helpful to define CCR2-CCR5 extended haplotypes for disease association purposes (Kaur \& Mehra, 2009).

\section{Genetic polymorphisms in CXC chemokines and their receptors}

\subsection{CXCL12 (SDF1)}

CXCL12 (SDF1) is a highly potent $\alpha$ chemokine, the natural ligand for the CXCR4, and a potent entry inhibitor for T-tropic (X4 or SI) HIV-1 strains that generally emerge during the late-stage of HIV-1 infection (Bleul et al., 1996). The CXCL12-CXCR4 interactions are essential for the homing and retention of hematopoietic progenitor cells in the bone marrow and have been shown to control the navigation of progenitor cells between the bone marrow and the blood. The gene for CXCL12 (SDF1) is $\sim 10 \mathrm{~kb}$ long and located on human chromosome 10q11.1. It exists in two isoforms, $\alpha$ and $\beta$, obtained as a consequence of alterative splicing. A common $\mathrm{G}$ to A transition, initially referred to as SDF1-3'A and currently named CXCL12-3' A, was described at an evolutionarily conserved sequence of the 3'UTR of the $\beta$ transcript gene. The polymorphism at the 801 position (G801A or CXCL12'A) has been shown to have a recessive protective effect against HIV-1 infection. Homozygotes for the CXCL12-3'A variant showed a remarkable level of protection against AIDS, supporting the hypothesis that the CXCL12-3'A variant restricts the emergency of X4 HIV-1 strains, with overproduction of CXCL12 in local compartments, which binds to and blocks the CXCR4 receptors required for X4 viruses to emerge and multiply (Winkler et al., 1998). However, direct evidence for an effect of CXCL12-3'A on the synthesis, quantity or half life of the ligand has not been obtained in vitro (Arya et al., 1999). Because CXCL12 expression is limited to stromal cells and other tissues that are not easy to quantify, this hypothesis is difficult to test in vivo (Bleul et al., 1996). 
Global, regional, and ethnic distributions of frequencies of CXCL12 genotypes and of the CXCL12-3'A allele vary significantly, ranging from 0.029-0.091 in Africans, 0.056-0.150 in American Indians, 0.149-0.217 in Europeans, 0.09- 0.380 in North Asians, 0.06-0.43 in South Asians, and 0.536- 0.7145 in Oceanian population (Su et al., 1999). In other ethnic cohorts, the allelic frequency of CXCL12-3' A ranged from 0.100 to 0.332 (Passam et al., 2005; Williamson et al., 2000; Wang et al., 2003). The frequency of the CXCL12 polymorphisms was also investigated in various cohorts of HIV-1 exposed but uninfected and among HIV-1 infected individuals. The results showed that the CXCL12-3'A allele delayed progression to AIDS but not decreased the susceptibility to HIV-1 infection (Winkler et al., 1998). Another study showed that the CXCL12-3'A homozygous mutation did not influence the clinical course of asymptomatic patients. However, the lower number of deaths during the follow-up period among symptomatic patients who were homozygotes and heterozygotes for the CXCL123 'A allele, suggested that both genotypes could have a possible late-stage protective effect on the clinical outcome of HIV-1 patients after the AIDS diagnosis (Reiche et al., 2006). However, the disease-retarding role of homozygosity for the CXCL12-3'A allele has not been confirmed in other cohorts (Mummidi et al., 1998; Wang et al., 2003; van Rij et al., 1998; Magierowska et al., 1999; Rousset et al., 1999; Brambilla et al., 2000; Soriano et al., 2002).

Verma et al. (2007) observed a low frequency of CCR5- $\Delta 32$ (1.5\%) and of CCR2-64I (9.1\%) in healthy Northern Indians, suggesting high vulnerability of North Indians to HIV-1 infection. However, the allelic frequency of the CXCL12 3'A was high (20.4\%) in the healthy HIV-1 seronegative Northern Indians included in their study, which was similar to that observed in South Indians (17.0\%-35.0\%) and South European populations (14.0\%-33.0\%) (Ramana et al., 2001).

Chaudhary et al. (2008) examined the SNP of CXCL12 3'A by polymerase chain reactionrestriction fragment length polymorphism (PCR-RFLP), cloning and sequencing in individuals from Northen India and showed that the genotypic frequency of CXCL12 3'A/CXCL12 3'A in the $100 \mathrm{HIV}-1$ seronegative healthy individuals, in $150 \mathrm{HIV}-1$ seronegative individuals with high risk for sexually transmitted disease (STD), and in 100 HIV-1 seropositive patients were $4.0 \%, 18.0 \%$ and $7.0 \%$, respectively. A significantly higher frequency of CXCL12 3'A/CXCL12 3'A was observed in high risk STD individuals as compared to HIV-1 seropositive $(p=0.014)$ and healthy HIV-1 seronegative tested individuals $(p=0.001)$, suggesting a protective role of CXCL12 3 ' A allele in HIV-1 infection. In this study it was observed a significant increase in the homozygous genotype for the mutant allele CXCL12 3'A in the high risk STD individuals as compared to both the healthy seronegative and HIV-1 seropositive individuals, suggesting a possible protective role of this allele in the homozygous state against HIV-1 infection.

The frequencies of CXCL12 3'A, CCR5- $\Delta 32$, CCR5-m3030, and CCR2-64I allelic variants were investigated in unrelated healthy Bahraini individuals without any known history of HIV-1 infection or AIDS symptoms. The results showed that CCR2-64I allele (8.9\%) and especially the CXCL12 3'A allele (26.5\%) were predominant and may be associated with resistance to fast HIV-1 infection in this population, and thus their genotyping could be used for prognosis in HIV-1 infected individuals. No mutant alleles were detected for CCR5m303A mutation and the frequency of $2.8 \%$ for CCR5- $\Delta 32$ allele may be attributed to the admixture with people of European descent (Salem et al., 2009).

The epidemiological interaction of CCR5/CCR2 and CXCL12-3'A suggests that a functional interaction might explain the enhanced protection. One hypothesis is that CCR2 and CCR5 
variants slow AIDS by limiting the number of CCR5 coreceptors that mediate the replication and spread of primary, early stage R5 HIV-1 strains, while the CXCL12-3'A variant restricts the emergence of X4 HIV-1 strains and the ensuing AIDS-accelerating process ( $\mathrm{O}^{\prime}$ Brien and Moore, 2000).

However, several studies show a lack of relationship between CXCL12 3'A and HIV-1 disease non-progression (Vidal et al., 2005a; Ioannidis et al., 2001; Tresoldi et al., 2002). For instance, in their international meta-analysis, Ioannidis et al. (2001) measured the effects of subjects homozygous for the CXCL12 3'A polymorphism by reviewing studies that prospectively followed HIV-1 infected patients from seroconversion to AIDS diagnosis and death. Results showed that being homozygous for the polymorphism had no effect on disease progression and there was no significant difference in HIV-1 RNA levels among persons with and without the polymorphism.

Recently, Tan et al. (2010) showed that the allelic frequency of CCR5- $\Delta 32$, CCR5m303A, CCR264I and CXCL12-3'A in HIV-1 infected and uninfected high-risk Uighurs individuals, the largest population of minority in China, was $4.4 \%, 2.7 \%, 25.7 \%$ and $57.4 \%$, respectively. While there was no significant difference in the frequency of CCR5- $\Delta 32$, CCR2-64I and CXCL12-3'A between HIV-1 seropositive and seronegative group, the frequency of CCR5m3030A in HIV-1 seropositive group was significantly higher than that in seronegative group. Furthermore, a woman who carried homozygous CCR5- $\Delta 32$ was positive for HIV-1 infection. Therefore, these data suggest that the CCR5- $\triangle 32$ CCR2-64I and CXCL1'3'A alleles may have limited effect on protecting from HIV-1 infection and CCR5m303A variant may be associated with the risk for HIV-1 infection in high-risk Uighurs individuals.

The distribution of CCR5- $\Delta 32$, CCR2-64I, and CXCL12 3'A alleles was evaluated in Guangxi Province Zhuang population, the largest minority ethnic population with over 15 million people, mainly located in Guangxi Province, China. The CCR5- $\Delta 32$ was absent, and CCR264I and CXCL12 3'A alleles were relatively common and seem not to confer protection against HIV-1 infection in this population. The results suggest that the Zhuang people may have a similar genetic susceptibility to HIV-1 infection with most other Chinese ethnic groups (Qijian et al., 2010).

\subsection{CXCR1, CXCR2}

CXCR1 (IL-8RA) and CXCR2 (IL-8RB) are receptors for IL-8, a proinflammatory cytokine involved in chemoattraction and activation of neutrophils. CXCR1 and CXCR2 genes are located o chromosome 2q35 and several polymorphisms have been described including SNPs T92G (CXCR1 -300) and C1003T (CXCR1-142) that result in a CXCR1 haplotype Ha. A genetic study on French cohort composing of rapid and slow progressors HIV-1 infected individual identified a strong association of CXCR1 haplotype Ha with protection against rapid progression to AIDS (Vasilescu et al., 2007). It was suggested that the inhibitory effect of CXCR1 Ha could be mediated by suppressing CD4 ${ }^{+}$and CXCR4 expression (Kaur \& Mehra, 2009).

\subsection{CXCR4}

The highly conserved CXCR4 gene is an obvious target as CXCR4 serves a coreceptor for X4 (SI) strains of HIV-1 to gain entry into cells. This gene is located on chromosome 2 and the screening of entire transcription unit resulted in the detection of two rare polymorphisms. 
One of these CXCR4 mutations was silent, and each was unique to two nonprogressors. However, no association with progression to AIDS was found (Cohen et al., 1998).

\subsection{CXCR6}

The CXCR6 is a chemokine receptor that is known as a minor coreceptor in HIV-1 infection but could participate in disease progression through its role as a mediator of inflammation. Petit et al. (2008) described the effects of mutation of acidic extracellular CXCR6 residues on receptor function. Although most CXCR6 mutants examined were expressed at levels similar to wild-type CXCR6, the N-terminal E3Q mutant was poorly expressed, which may explain previously reported protective effects of a similar SNP, with respect to late-stage HIV-1 infection. In contrast to several other chemokine receptors, mutation of the CXCR6 Nterminal and inhibition of post-translational modifications of this region were without effect on receptor function. This data suggests a novel paradigm for the CXCR6:CXCL16 interaction, a finding which may impact the discovery of small-molecule antagonists of CXCR6.

Study by Limou et al. (2010) verified that the rs2234358 polymorphism in the CXCR6 gene was the strongest signal obtained for the genomewide association study comparing the 186 Genomics of Resistance to Immunodeficiency Virus (GRIV) LTNPs who were not elite controlls with 697 uninfected control subjects. This association was replicated in 3 additional independent European studies, reaching genomewide significance. This association with LTNPs is independent of the CCR2-CCR5 loci and the HCP5 polymorphisms. The statistical significance, the replication, and the magnitude of the association demonstrate that CXCR6 is likely involved in the molecular etiology of AIDS and, in particular, in LTNPs, emphasizing the power of extreme-phenotype cohorts.

\section{Genetic polymorphisms in $\mathrm{CX}_{3} \mathrm{C}$ Chemokine Receptor $\left(\mathrm{CX}_{3} \mathrm{CR}\right)$}

\section{1 $\mathrm{CX}_{3} \mathrm{CR} 1$}

$\mathrm{CX}_{3} \mathrm{CR} 1$, a leukocyte chemotactic and adhesion receptor for the human chemokine fractalkine, has also been defined as a minor HIV-1 coreceptor, particularly expressed on brain. Mutations on the $\mathrm{CX}_{3} \mathrm{CR} 1$ gene, located at chromosome 3, have been described, such as V249I (substitution changed Valine to Isoleucine) and T280M (substitution changed Threonine to Methionine) (Faure et al., 2000), with frequency of $26.0 \%$ and $13.0 \%$, respectively. The impact of $\mathrm{CX}_{3} \mathrm{CR} 1$ polymorphisms on HIV-1 pathogenesis is controversial, with conflicting reports of their role in disease progression in HIV-1 infected patients. Individuals homozygous for the $280 \mathrm{M}$ allele exhibited accelerated disease progression (Faure et al., 2000, 2003), with a small but statistically significant correlation with slightly earlier immunological and virologic failure (Brumme et al., 2003). However, further studies did not confirm this observation (McDermott et al., 2000; Kwa et al., 2003).

Polymorphisms in CCR2 and $\mathrm{CX}_{3} \mathrm{CR} 1$, which HIV-1 sometimes uses as coreceptors, have also been associated with slowing HIV-1 disease progression. For example, the CCR2-64I mutation has been shown to reduce CXCR4 expression on $\mathrm{CD}^{+} \mathrm{T}$ cells, thereby interfering with X4-tropic virus infection (Kalinkovich et al., 1999). In one study's cohort of HIV-1 positive Kenyan sex workers (Anzala et al., 1998), the frequency of being positive for CCR2$64 I$ was highest in LTNPs, which was three times greater than that for progressors. In a separate study, Vidal et al. (2005b) found that the $C X_{3} C R 1$ V249I polymorphism is 
significantly more frequent in LTNPs than progressors, but not than healthy controls. It has been observed that there was a large discrepancy between these alleles among populations of the north and south. Populations in the same language-speaking family or with the same origin shared similar allele distributions.

Puissant et al. (2006) observed that some genetic polymorphisms had an impact on the evolution of plasma virus load and peripheral T lymphocyte counts in HIV-1 infected patients under HAART. After 1 year of HAART, patients with a virological response (undetectable plasma HIV-1 RNA) have a higher frequency of the homozygous CXCL12 3' A genotype than patients with other polymorphisms such as CCR5- $\triangle 32$, CCR2-64I, CX 3 CR1249I, and $C_{3}$ CR1-280M. Similarly, patients with a CD4 ${ }^{+}$T cell increase of over $200 / \mathrm{mm}^{3}$ from baseline after 1 year of HAART display higher frequencies of homozygous CXCL12 $3^{\prime} \mathrm{A}$ and homozygous $\mathrm{CX}_{3} \mathrm{CR} 1-280 \mathrm{M}$ genotypes than other patients. Moreover, the authors showed that $\mathrm{CX}_{3} \mathrm{CR} 1-280 \mathrm{M}$ allele was associated with high peripheral $\mathrm{CD}^{+} \mathrm{T}$ cell counts not only in HIV-1 soropositive patients but also in healthy controls.

Qian et al. (2008) showed that the frequencies of $\mathrm{CX}_{3} \mathrm{CR} 1-249 \mathrm{I}$ and $280 \mathrm{M}$ alleles varied substantially among different population and were independent risk factors for accelerating the progression to AIDS. Further, Parczewski et al. (2009) studied the influence of genetic variants for CCR5-432, CCR5 -G2459A, CCR2- G190A, CX ${ }_{3}$ CR1- G744A, and CX ${ }_{3}$ CR1C838T in a cohort of $168 \mathrm{HIV}-1$ seropositive adults and 151 healthy newborns from northwestern Poland. The results showed that haplotypes containing CCR5- $\Delta 32$, CCR2G190A, and $\mathrm{CX}_{3} \mathrm{CR} 1-\mathrm{G} 744 \mathrm{~A}$ were significantly more common in the healthy newborns suggesting an association between these haplotypes and resistance to HIV-1 infection in this population.

\section{Genetic polymorphism in cytokines and their receptors}

Like chemokines, the role of cytokines in the modulation of HIV-1 infection and the rate of disease progression remains to be fully understood. Evidence of strong epidemiological associations between cytokines and HIV-1 disease progression has been limited and, in some cases, inconsistent across studies. Studies have shown that cytokines can have inhibitory, stimulatory or both effects on HIV-1 replication (Han et al., 1996; Naif et al., 1997).

\subsection{Interleukin-4 (IL-4) and IL-4 Receptor (IL-4R)}

IL-4 is an important cytokine that induces differentiation of $\mathrm{CD}^{+}{ }^{+} \mathrm{Th}$ cells. It also regulates the expression of the HIV-1 coreceptors CCR5 and CXCR4. IL-4 decreases the levels of CCR5 on the surfaces of CD4-bearing cells and increases CXCR4 levels on the same or other cells. $I L-4$ gene is located on chromosome 11 and a SNP in the regulatory region of IL-4 gene (IL4-589 C/T), initially identified among HIV-1 seropositive Japanese individuals, has been reported to have a protective effect against transmission of HIV-1 through heterosexual contact. The IL4-R alpha I50V polymorphism in exon 5 of IL-4R gene affects the functional responsiveness of the gene (Risma et al., 2002). The SNP I50V was found to be associated with slow progression to AIDS in HIV-1 infected individuals (Soriano et al., 2005). However, another study suggested an association of IL-4R alpha I50V allele with increased likelihood of HIV-1 infection in North Indian population (Chatterjee et al., 2009). 


\subsection{Interleukin 10 (IL-10)}

The interleukin-10 (IL-10) is known to inhibit HIV-1 replication in macrophages in vivo (Kollmann et al., 1996). The gene encoding IL-10 is situated on chromosome 1 and a polymorphism with $\mathrm{C} \rightarrow \mathrm{A}$ transition in the promoter region at position -592, named IL10C592A, has been associated with diminished IL-10 production and accelerated progression to AIDS with a dominant effect (Winkler et al., 1998). This SNP is carried by $23.6 \%$ of the Caucasians, $40.0 \%$ of the African Americans, 33.0\% of Hispanics, and $60.0 \%$ of the Asians. The molecular mechanism behind this SNP is not well understood but is has been predicted that IL-10 may control proliferation of HIV-1 by limiting the number of activated macrophages available for HIV-1 replication (Chatterjee, 2010).

\subsection{Tumor Necrosis Factor Alpha (TNF- $\alpha$ )}

TNF- $\alpha$ is a pro-inflammatory cytokine and is known to be involved in the various immunogenetic events that influence HIV-1 infection. The gene encoding TNF- $\alpha$ is located on chromosome 6 and four polymorphisms in the TNF- $\alpha$ promoter have been identified, all with $\mathrm{G} \rightarrow$ A transitions; however, the information available of how TNF- $\alpha$ genetic variants affect vulnerability to HIV-1 infection is inconsistent (reviewed by Chatterjee, 2010). Veloso et al. (2010) determined whether carriage of the TNF- $\alpha-238 \mathrm{G} / \mathrm{A},-308 \mathrm{G} / \mathrm{A}$, and $-863 \mathrm{C} / \mathrm{A}$ gene promoter SNPs influence the risk of HIV-1 infection and disease progression in Caucasian Spaniards. For this purpose, 239 heavily exposed but uninfected individuals (EU), 203 healthy controls (HC), 109 HIV-1 infected typical progressors (TP) and 75 HIV-1 infected LTNPs were evaluated. The results showed that the distribution of TNF- $\alpha$ variants did not differ among HIV-1 infected compared with EU and among TP and LTNPs. The analysis in LTNPs subset indicated that TNF- $\alpha-238 \mathrm{~A}$ variant allele was significantly overrepresented in patients who spontaneously controlled plasma viremia compared with those who had a detectable plasma viral load. Taken together, the results suggested that TNF- $\alpha$ genetic variants were unrelated to disease progression in infected subjects but the 238 G/A SNP may modulate the control of viremia in LTNPs.

\subsection{Interferon alpha receptor 1 (IFNAR1)}

Interferon alpha (IFN- $\alpha$ ) elicits a pleotropic antiviral response and form the first line of defense against HIV-1 infection. This cytokine acts through the IFN- $\alpha$ receptor (IFNAR) that is composed of two subunits, IFNAR1 and IFNAR2, encoded by the gene located at chromosome 21q (Kim et al., 1997). Two SNPs in the IFNAR1 gene, IFNAR1-18339G $\rightarrow$ C (Valine to Leucine change in exon) and IFNAR1-30127C $\rightarrow \mathrm{T}$ (in intron), found in tight linkage disequilibrium were associated with susceptibility to HIV-1 infection (Diop et al., 2006).

\section{Genetic polymorphism and the response to antiretroviral therapy}

The observations that genetic markers influence the natural history of HIV-1 and that the infection and the immunological and virologic responses to HAART is neither universal nor homogeneous (DeHovitz et al., 2000), lead to the thought that the response to treatment may also be genetically determined. Polymorphisms in the chemokine and chemokine receptor genes may affect response to HAART, in addition to other host factors governing poor immune response to HAART, such as increasing age (Viard et al., 2001), injection drug use 
(Dronda et al., 2002), hepatitis C virus coinfection (Greub et al., 2000), and lower baseline CD4 ${ }^{+} \mathrm{T}$ cell count (Vaamonde et al., 2006).

Genetic polymorphisms could also explain the heterogeneity in sustaining viral suppression observed among patients receiving HAART (O'Brien et al., 2000). Approximately $10.0 \%$ of HIV-1 infected patients do not respond to HAART with a reduction of viral load, even if there is good compliance and no evidence of viral resistance (Lederberger et al., 1999).

However, studies investigating the association between genetic polymorphisms and response to HAART have provided conflicting data. An improvement in the immunological and the virological responses in association with the CCR5- $\triangle 32$, CCR2-64I, CXCL12-3' A, and CCR5-59029G/A polymorphisms has been reported (O'Brien et al., 2000; Guerin et al., 2000; Kasten et al., 2000; Yamashita et al., 2001). HIV-1 infected patients with wild type genotypes for the CCR5, CCR2, and 59029A alleles treated with HAART had the poorest response to therapy compared with patients with other genotypes combined with the CCR5- $\triangle 32$, CCR64I or 59029G alleles ( $\mathrm{O}^{\prime}$ Brien et al., 2000). Polymorphism within the $C X_{3} C R 1$ gene was associated with accelerated virological and immunological therapy failure (Brumme et al., 2003). One report (Puissant et al., 2006) showed that, after one year of HAART, patients with undetectable plasma HIV-1 RNA levels have a higher frequency of the homozygous CXCL12-3'A genotype than other patients. Similarly, patients with a CD4+T cell count increase of over $200 / \mathrm{mm}^{3}$ from baseline after one year of HAART display higher frequencies of homozygous CXCL12-3'A and CX ${ }_{3}$ CR1-280M genotypes than other patients.

Another study that evaluated a subgroup of patients with baseline CD4 ${ }^{+} \mathrm{T}$ cell count of 201500 cells $/ \mathrm{mm}^{3}$, showed that both the CXCL12-3' A and CCR2-64I alleles displayed a positive influence on clinical progression after HAART initiation. The CXCL12-3'A allele showed this effect through a more rapid $\mathrm{CD}^{+} \mathrm{T}$ lymphocyte restoration counts above the level of 500 cells $/ \mathrm{mm}^{3}$, while CCR2-64I was associated with stronger viral suppression. Regarding the CCR5- $\triangle 32$ and CCR5-59029G/A alleles, they had no effects on the response to HAART initiation (Passam et al., 2005). In contrast, other studies did not find such correlation (Brumme et al., 2001; Bratt et al., 1998; Wit et al., 2002). However, one of these studies (Bratt et al., 1998) did not exclude nonadherent patients, and analyzed their data on an intent-totreat basis, thus reducing the likelihood of finding a difference. In addition, $69.0 \%$ of their CCR5/ $\triangle 32$ heterozygous patients had SI virus isolates, and therefore, tended to have lower $\mathrm{CD}^{+} \mathrm{T}$ cell counts, higher plasma HIV-1 RNA levels, and a greater proportion of azidothymidine resistance mutations.

Another study evaluated the CCR5- $\triangle 32$, CXCL12-3'A, and CCR2-64I genetic polymorphisms in HIV-1 infected patients receiving HAART and the results showed that successful treatment was associated with heterozygosity for the CCR5- $\Delta 32$, underscoring that the chemokine receptor polymorphisms have a modifying effect on the virological response to HAART. The course of mean viral load was significantly worse for patients without the CCR5- $\triangle 32$ allele and the multivariate analysis demonstrated that heterozygosity for the CCR5- $\Delta 32$ variant is an independent prognostic factor for treatment outcome (Bogner et al., 2004).

The frequency of the CXCL12- 3'A, CCR2-64I, CCR5- 332 , and CCR5-Promoter-59029-A/G polymorphisms was also evaluated in 155 Brazilian HIV-1 infected on pre and post-HAART and their influence on $\mathrm{CD} 4^{+} \mathrm{T}$ cell counts. The results showed that the $\mathrm{CD}^{+} \mathrm{T}$ cell gain was influenced by carriage of one or more of these polymorphisms, highlighting the possibility that these genetic traits can be useful to identify patients at risk for faster progression to AIDS or therapeutic failure (Rigatto et al., 2008). 
The chemokine polymorphisms CXCR6-3E/K, In1.1T/C, H7 haplotype, CX 3 CR1-V249I, and $\mathrm{CX}_{3} \mathrm{CR} 1-\mathrm{T} 280 \mathrm{M}$ have been shown to affect the course of HIV-1 infection. The influence on immunologic and virologic response to HAART in a group of $143 \mathrm{HIV}-1$ patients was studied by Passam et al. (2007). The results revealed an improved immunologic response to HAART in patients with the $\mathrm{CX}_{3}$ CR1-249I or CX3CR1-280M allele. On the contrary, patients with initial viral load suppression due to HAART showed a faster virologic failure in the presence of the CXCR6-3K allele. The In1.1T/C polymorphism and H7 haplotype did not reveal any specific effect on HAART response.

\section{Conclusion}

So far, the CCR5- $\triangle 32$ allele remains the most important host factor known to be associated to the resistance to the HIV-1 infection. However, high frequencies of CCR5- $\Delta 32$, CCR2-64I, and CXCL12-3' A alleles could be all the aftermath or adaptive episodes in which a pathogen exerted selective pressure favoring the survival of persons with these beneficial alleles.

Taken together, the reviewed studies suggest that the existence of genetic polymorphisms must be taken into account in the virological and immunological follow-up of HIV-1 infected patients under treatment with HAART, and that pharmacogenetics is very likely to influence the future individualization of HAART. The individual genetic conditions could be of interest not only in terms of disease progression, but also on the drug metabolism, and therapy response. The identification of genetic polymorphisms in the HIV-1 infected individuals could be useful to identify a possible genotype or genotype associations that could serve as a marker of either the disease progression in HIV-1 infected individuals or of a higher probability of HAART failure.

Genetic markers could also be useful to better characterize the genetic epidemiology of HIV1 infection and to detect individuals at high risk of a faster disease progression. This information could lead to the use of different or more aggressive therapeutic strategies, the monitoring in shorter interval of time, or both procedures. Most of the studies reviewed here signaled that the chemokine receptor antagonists are important new antiviral drugs to combat the HIV-1 infection. HIV-1 infected patients in the advanced stages of the disease and/or with multiresistance to the antiretroviral agents currently available could benefit from these new therapeutic strategies.

It is possible that a multifaceted approach to antiretroviral therapy, which takes into account the genetic host factors and the use of combinations of inhibitors that target different steps of the viral life cycle, has the best potential for long-term control of HIV-1 infection. Such approach could lead to the optimal therapeutic effects of reducing viral loads and some immune restoration response, and also to an increase in the span of life of infected individuals. In this post-genomic era, the study of host factors and their genetic contribution to HIV-1 infection, addresses fundamental issues in our understanding of the pathogenesis of the infection and opens new opportunities for therapeutic intervention to be developed.

\section{References}

An, P.; Johnson, R.; Phair, J.; Kirk, G.D.; Yu, X-F.; Donfield, S.; Buchbinder, S.; Goedert, J.J. \& Winkler, C.A. (2009). APOBEC3B deletion and risk of HIV-1 acquisition. The Journal of Infectious Diseases, v.200, pp.1054-1058, ISSN 0022-1899. 
An, P.; Martin, M.P.; Nelson, G.W.; Carrington, M.; Smith, M.W.; Gong, K.; Vlahov, D.; O'Brien, S.J. \& Winkler, C.A. (2000). Influence of CCR5 promoter haplotypes on AIDS progression in African-Americans. AIDS, v. 14, n. 14, pp. 2117-2122, ISSN 0269-9370.

An, P.; Nelson, G.W.; Wang, L.; Donfield, S.; Goedert, J.J.; Phair, J.; Vlahov, D.; Buchbinder, S.; Farrar, W.L.; Modi, W.; O'Brien, S.J. \& Winkler, C.A. (2002). Modulating influence on HIV/AIDS by interacting RANTES gene variants. Proceedings National Academy of Sciences U S A, v. 99, pp. 10002-10007, ISSN 0027-8424.

Anzala, A.O.; Ball, T.B.; Rostron, T.; O'Brien, S. J.; Plummer, F.A. \& Rowland-Jones, S.L. (1998). CCR2-64I allele and genotype association with delayed AIDS progression in African women. University of Nairobi Collaboration for HIV Research. The Lancet, v. 351, pp. 1632-1633, ISSN 0099-5355.

Arenzana-Seisdedos, F. \& Parmentier, M. (2006). Genetics of resistance to HIV infection: role of co-receptors and co-receptor ligands. Seminars in Immunology, v. 18, pp. 387-403, ISSN 1044-5323.

Arenzana-Seisdedos, F.; Virelizier, J-L.; Rousset, D.; Clark-Lewis, I.; Loetscher, P.; Moser, B. \& Baggiolini, M. (1996). HIV blocked by chemokine antagonist. Nature, v. 383, n. 6599, pp.400, ISSN 0028-0836.

Arya, S.K.; Ginsberg, C.C.; Davis-Warren, A. \& D'Costa, J. (1998). In vitro phenotype of SDF1 gene mutant that delay the onset of human immunodeficiency virus disease in vivo. Journal of Human Virology, v.2, p. 133-138, ISSN 1090-9508.

Balotta, C.; Bagnarelli, P.; Violin, M.; Ridolfo, A.L.; Zhou, D.; Berlusconi, A.; Corvasce, S.; Corbellino, M.; Clementi, M.; Clerici, M.; Moroni, M. \& Galli, M. (1997). Homozygous delta 32 deletion of the CCR5-chemokine receptor gene in an HIV-1infected patient. AIDS, v. 11, n.10, pp. F67-F71, ISSN 0269-9370.

Biti, R.; Ffrench, R.; Young, J.; Bennets, B.; Steward, G. \& Liang, T. (1997). HIV-1 infection in an individual homozygous for the CCR5 deletion allele. Nature Medicine., v. 3, n.3, pp. 252-253, ISSN 1078-8956.

Bleul, C.C.; Farzan, M.; Choe, H.; Parolin, C.; Clark-Lewis, I.; Sodoski, J.; Springer, T.A. (1996). The lymphocyte chemoattractant SDF-1 is a ligand for LESTR/fusin and blocks HIV-1 entry. Nature, v. 382, n. 6594, p. 829-833, ISSN 0028-0836.

Bogner, J.; Lutz, B.; Klein, H.G.; Pollerer, C.; Troendle, U. \& Goebel, F.D. (2004). Association of highly active antiretroviral therapy failure with chemokine receptor 5 wild type. HIV Medicine, v. 5, n. 4, pp. 264-272, ISSN 1464-2662.

Brambilla, A.; Villa, C.; Rizzardi, G.; Veglia, F.; Ghezzi, S.; Lazzarin, A.; Cusini, M.; Muratori, S.; Santagostino, E.; Gringeri, A.; Louie, L.G.; Sheppard, H.W.; Poli, G.; Michael, N.L.; Pantaleo, G. \& Vicenzi, E. (2000). Shorter survival of SDF1-3'A homozygotes linked to CD4+ $\mathrm{T}$ cell decrease in advanced human immunodeficiency virus type 1 infection. The Journal of Infectious Diseases, v. 182, n. 1, p. 311-315, ISSN 0022-1899.

Brass, A.L.; Dykxhoom, D.M.; Benita, Y.; Yan, N.; Engelman, A.; Xavier, R.J.; Lieberman, J. \& Elledge, S.J. (2008) Identification of host proteins required for HIV infection through a functional genomic screen. Science, v. 319, n.5868, pp.921-926, ISSN 00368075.

Bratt, G.; Karlsson, A.; Leandersson, A.C.; Albert, J.; Wahren, B. \& Sandstrom, E. (1998). Treatment history and baseline viral load, but not viral tropism or CCR-5 genotype, 
influence prolonged antiviral efficacy of highly active antiretroviral treatment. AIDS, v. 12, n.16, pp. 2193-2202, ISSN 0269-9370.

Brumme, Z.L.; Chan, K.J.; Dong, W.; Hogg, R.; O'Shaughnessy, M.V.; Montaner, J.S. \& Harrigan, P.R. (2001). CCR5Delta32 and promoter polymorphisms are not correlated with initial virological or immunological treatment response. AIDS, v. 15, n.17, pp. 2259-2266, ISSN 0269-9370.

Brumme, Z.L.; Dong, W.W.Y.; Chan, K.J.; Hogg, R.S.; Montaner, J.S.C.; O'Shaughnessy, M.V. \& Harrigan, P.R. (2003). Influence of polymorphisms within the CX3CR1 and MDR1 genes on initial antiretroviral therapy response. AIDS, v. 17, n.2, pp. 201-208, ISSN 0269-9370.

Carrington, M.; Kissner, T.; Gerrard, B.; Ivaniv, S.; O’Brien, S.J.; Dean, M.A. (1997). Novel alleles of the chemokine-receptor gene CCR5. Journal of Human Genetics, v. 61, n. 6, pp. 1261-1267, ISSN 1434-5161.

Carrington, M.; Nelson, G.W.; Martin, M.P.; Kissner, T.; Vlahov, D.; Goedert, J.J.; Kaslow, R.; Buchbinder, S.; Hoots, K. \& O'Brien, S.J. (1999). HLA and HIV-1: heterozygosity advantage and $\mathrm{B}^{\star} 35-\mathrm{Cw}^{*} 04$ disadvantage. Science, v. 283, p. 1748-1752, ISSN 00368075.

Chatterjee, A.; Rathone, A. \& Dhole, T.N. (2009). Association of IL-4 589 C/T promoter and Il-4RalphaI50V receptor polymorphism with susceptibility to HIV-1 infection in North Indians. Journal of Medical Virology, v.81, n.6, pp.959-956, ISSN 0146-6615.

Chatterjee, K. (2010). Host genetic factors in susceptibility to HIV-1 infection and progression to AIDS. Journal of Genetics, v.89, n.1, pp.109-116, ISSN 0022-1333.

Chaudhary, O.; Rajsekar, K.; Ahmed, I.; Verma, R.; Bala, M.; Bhasinc, R. \& Luthra, K. (2008). Polymorphic variants in DC-SIGN, DC-SIGNR and SDF-1 in high risk seronegative and HIV-1 patients in Northern Asian Indians. Journal of Clinical Virology, n. 43, pp. 196-201, ISSN 1386-6532.

Cohen, O.J.; Kinter, A. \& Fauci, A.S. (1997). Host factors in the pathogenesis of HIV disease. Immunological Reviews, v. 159, pp. 31-48, ISSN 0105-2896.

Cohen, O.J.; Paolucci, S.; Bende, S. M.; Daucher, M.; Moriuchi, H.; Moriuchi, M.; Cicala, C.; Davey, R.T. Jr.; Baird. B. \& Fauci, A.S. (1998). CXCR4 and CCR5 genetic polymorphisms in long-term nonprogressive human immunodeficiency virus infection: lack of association with mutations other than CCR5-Delta32. Journal of Virology, v.72, n. 7, pp. 6215-6217, ISSN 0022-538X.

Cohen, O.J.; Vaccarezza, M.; Lam, G.K.; Baird, B.; Wildt, K.; Murphy, P.M.; Zimmerman, P.A.; Nutman, T.B.; Fox, C.H.; Hoover, S.; Adelsberger, K.J.; Baseler, M.; Arthos, J.; Davey, R.T.; Dewar, R.L.; Metcalf, J.; Schwartzentruber, D.J.; Orenstein, J.M.; Buchbinder, S.; Saah, A.J.; Detels, R.; Phair, J.; Rinaldo, C.; Margolick, J.B.; Pantaleo, G. \& Fauci, A.S. (1997). Heterozygosity for a defective gene for CC chemokine receptor 5 is not the sole determinant for the immunologic and virologic phenotype of HIV-infected long-term nonprogressors. The Journal of Clinical Investigation, v. 100, n. 6, pp. 1581-1589, ISSN 0021-9738.

de Roda Husman, A.M.; Koot, M.; Cornelissen, M.; Keet, I.P.M.; Brouwer, M.; Broersen, S.M.; Bakker, M.; Roos, M.T.; Prins, M.; de Wolf, F.; Coutinho, R.A.; Miedema, F.; Goudsmit, J. \& Schuitemaker, H. (1997). Association between CCR5 genotype and the clinical course of HIV-1 infection. Annals of Internal Medicine, v. 127, n. 10, pp. 882-890, ISSN 0003-4819. 
Dean, M.; Carrington, M.; Winkler, C.; Huttley, G.A.; Smith, M.W.; Allikmets, R.; Goedert, J.J.; Buchbinder, S.P.; Vittinghoff, E.; Gomperts, E.; Donfield, S.; Vlahov, D.; Kaslow, R.; Saah, A.; Rinaldo, C.; Detels, R. \& O'Brien, S.J. (1996). Hemophilia growth and development study, Multicenter AIDS Cohort Study, Multicenter Hemophilia Cohort Study, San Francisco City Cohort, Alive Study, O'Brien, S.J†. Genetic restriction of HIV-1 infection and progression to AIDS by a deletion allele of the CKR5 structural gene. Science, v. 273, n.5823, pp. 1856-1862, ISSN 0036-8075.

DeHovitz, J.A.; Kovacs, A.; Feldman, J.G.; Anastos, K.; Young, M.; Cohen, M.; Gange, S.J.; Melnick, S. \& Greenblatt, R.M. (2000). The relationship between virus load response to highly active antiretroviral therapy and change in CD4 cell counts: A report from the Women's interagency HIV study. The Journal of Infectious Diseases, v. 182, n. 5, pp. 1527-1530, ISSN 0022-1899.

Diop, G.; Hirtzig, T.; Do, H.; Coulonges, C.; Vasilescu, A.; Labib, T.; Spadoni, J.L.; Therwath, A.; Lathrop, M.; Matsuda, F. \& Zagury, J.F. (2006). Exhaustive genotyping of the interferon alpha receptor 1 (IFNAR1) gene and association of an IFNAR1 protein variant with AIDS progression or susceptibility to HV-1 infection in a French AIDS cohort. Biomedicine and Pharmacotherapy, v.60, n.9, pp. 569-577, ISSN 0753-3322.

Dronda, F.; Moreno, S.; Moreno, A.; Casado, J.L.; Perez-Elias, M.J. \& Antela, A. (2002). Longterm outcomes among antiretroviral-naive human immunodeficiency virusinfected patients with small increases in CD4+ cell counts after successful virologic suppression. Clinical Infectious Diseases, v. 35, n. 8, pp. 1005-1009, ISSN 1058-4838.

Eugen-Olsen, J.; Iversen, A.K.; Benfield, T.L.; Koppelhus, U. \& Garred, P. (1998). Chemokine receptor CCR2b 64I polymorphism and its relation to CD4 T-cell counts and disease progression in a Danish cohort of HIV-infected individuals. Copenhagen AIDS cohort. Journal of Acquired Immune Deficiency Syndrome and Human Retrovirology, v. 18, n. 2, pp. 110-116, ISSN 1077-9450.

Eugen-Olsen, J.; Iversen, A.K.; Garred, P.; Koppelhus, U.; Pedersen, C.; Benfield, T.L.; Sorensen, A.M.; Katzenstein, T.; Dickmeiss, E.; Gerstoft, J.; Skinhoj, P.; Svejgaard, A.; Nielsen, J.O. \& Hofmann, B. (1997). Heterozygosity for a deletion in the CKR-5 gene leads to prolonged AIDS-free survival and slower CD4 T-cell decline in a cohort of HIV-seropositive individuals. AIDS v. 11, n.3, pp. 305-310, ISSN 02699370 .

Fauci, A.S.; Pantaleo, G.; Stanley, S. \& Weissman, D. (1996). Immunopathogenic mechanisms of HIV infection. Annals of Internal Medicine, v. 124, pp. 654-663, ISSN 0003-4819.

Faure, S.; Meyer, L.; Costagliola, D.; Vaneensberghe, C.; Genin, E.; Autran, B.; Delfraissy, J.F.; McDermott, D.H.; Murphy, P.M.; Debré, P.; Théodorou, I. \& Combadière, C. (2000). Rapid progression to AIDS in HIV+ individuals with a structural variant of the chemokine receptor CX3CR1. Science, v. 287, n. 5461, pp. 2274-2277, ISSN 00368075 .

Faure, S.; Meyer, L.; Genin, E.J.; Pellet, P.; Debre, P.; Theodorou, I. \& Combadiere, C. SEROCO Study Group. (2003). Deleterious genetic influence of CX3CR1 genotypes on HIV-1 disease progression. Journal of Acquired Immune Deficiency Syndrome, v. 32, n.3, pp. 335-337, ISSN 1525-4135.

Gonzalez, E.; Bamshad, M.; Sato, N.; Mummidi, S.; Dhanda, R.; Catano, G.; Cabrera, S.; McBride, M.; Cao, X.H.; Merrill, G.; O'Connell, P.; Bowden, D.W.; Freedman, B.I.; 
Anderson, S.A.; Walter, E.A.; Evans, J.S.; Stephan, K.T.; Clark, R.A.; Tyagi, S.; Ahuja, S.S.; Dolan, M.J. \& Ahuja, S.K. Race-specific HIV-1 disease-modifying effects associated with CCR5 haplotypes. Proceedings of the National Academy of Sciences USA, v.96, pp12004-12009, ISSN 0027-8424.

Gonzalez, E.; Kulkarni, H.; Bolivar, H.; Mangano, A.; Sanchez, R.; Catano, G.; Invs., R.J.; Freedman, B.I.; Quinones, M.P.; Bamshad, M.J.; Murthy, K.K.; Rovin, B.H.; Bradley, W.; Clark, R.A.; Anderson, S.A.; O'Connell, R.J.; Agan B.K.; Ahuja, S.S.; Bologna, R.; Sen, L.; Dolan, M.J \& Ahuja, S.K. (2005). The influence of CCL3L1 gene-containing segmental duplications on HIV-1/AIDS susceptibility. Science, v. 307, n. 5714, pp. 1434-1440, ISSN 0036-8075.

Greub, G.; Ledergerber, B.; Battegay, M.; Grob, P.; Perrin, L.; Furrer, H.; Burgisser, P.; Erb, P.; Boggian, K.; Piffaretti, J.C.; Hirschel, B.; Janin, P.; Francioli, P.; Flepp, M. \& Telenti, A. (2000). Clinical progression, survival, and immune recovery during antiretroviral therapy in patients with HIV-1 and hepatitis C virus coinfection: the Swiss HIV Cohort Study. The Lancet, v. 356, n.9244, pp. 1800-1805, ISSN 0099-5355.

Guerin, S.; Meyer, L.; Theodorou, I.; Boufassa, F.; Magierowska, M.; Goujard, C.; Rouzious, C.; Debre, P.; Delfraissy, J.F.; SEROCO/HEMOCO Study Group. (2000). CCR5 delta32 deletion and response to highly active antiretroviral therapy in HIV-1infected patients. AIDS, v. 14, n. 17, pp. 2788-2790, ISSN 0269-9370.

Han, X.; Becker, K.; Degen, H.J. Jablonowski, H. \& Strohmeyer, G. (1996). Synergistic stimulatory effects of tumor necrosis factor alpha and interferon gamma on replication of human immunodeficiency virus type 1 and on apoptosis of HIV-1infected host cells. European Journal of Clinical Investigation, v.26, n.4, pp. 286-292, ISSN 0014-2972.

Ioannidis, J.P.; O'Brien, T.R.; Rosenberg, P.S.; Contopoulos-Ioannidis, D.G. \& Goedert, J.J. (1998). Genetic effects on HIV disease progression. Nature Medicine, v. 4, n.5, pp. 536, ISSN 1078-8956.

Ioannidis, J.P.A.; Rosenberg, P.S.; Goedert, J.J.; Ashton, L.J.; Benfield, T.L.; Buchbinder, S.P.; Coutinho, R.A.; Eugen-Olsen, J.; Gallart, T.; Katzenstein, T.L.; Kostrikis, L.G.; Kuipers, H.; Louie, L.G.; Mallal, S.A.; Margolick, J.B.; Martinez, O.P.; Meyer, L.; Michael, N.L.; Operskalski, E.; Pantaleo, G.; Rizzardi, G.P.; Schuitemaker, H.; Sheppard, H.; Stewart, G.J.; Theodorou, I.D.; Henrik, U.; Vicenzi, E.; Vlahov, D.; Wilkinson, D.; Workman, C.; Zagury, J-F. \& O'Brien, T.R. (2001). Effects of CCR5Delta32, CCR2-64I, and SDF-1 3'A alleles on HIV-1 disease progression: an international meta-analysis of individual-patient data. Annals of Internal Medicine, v. 135, pp. 782-795, ISSN 0003-4819.

Jang, D. H.; Choi, B.S. \& Kim, S.S. (2008). The effects of RANTES/CCR5 promoter polymorphisms on HIV disease progression in HIV-infected Koreans. International Journal of Immunogenetics, v. 35, pp. 101-105, ISSN 1744-3121.

Kalinkovich, A.; Weisman, Z. \& Bentwich, Z. (1999). Chemokines and chemokine receptors: role in HIV infection. Immunological Letters, v. 68, pp. 281-287.

Kasten, S.; Goldwich, A.; Schmitt, M.; Rascu, A.; Grunke, M.; Dechant, C.; Kalden, J.R. \& Harrer. T. (2000). Positive influence of the Delta32CCR5 allele on response to highly active antiretroviral therapy (HAART) in HIV-1 infected patients. European Journal of Medical Research, v. 5, n. 8, pp. 323-328, ISSN: 0949-2321. 
Kaur, G. \& Mehra, N. (2009). Genetic determinants of HIV-1 infection and progression to AIDS: susceptibility to HIV infection. Tissue Antigens, v.73, pp.289-301, ISSN 00012815.

Kaur, G.; Singh, P.; Kumar, N.; Rapthap, C.C.; Sharma, G.; Vajpayee, M.; Wig, N.; Sharma, S.K. \& Mehra, N.K. (2007). Distribution of CCR2 polymorphism in HIV-1 infected and healthy subjects in North India. International Journal of Immunogenetics, v. 34, n.3, pp. 153-156, ISSN 1744-3121.

Kaur, G.; Singh, P.; Rapthap, C.C.; Kumar, N.; Vajpayee, M.; Sharma, S.K.; Wanchu, A. \& Mehra, N.K. (2007). Polymorphism in the CCR5 gene promoter and HIV-1 infection in North Indians. Human Immunology, v. 68, n.5, pp. 454-461, ISSN 0198-8859.

Kim, S.H.; Cohen, B.; Novick, D. \& Rubinstein, M. (1997). Mamalian type I interferon receptors consits of two subunits: IFNaR1 and IFNaR2. Gene, v. 196, n.1-2, pp.279286, ISSN 0378-1119.

Kolmann, T.R.; Pettoello-Mantovani, M.; Katopodis, N.F.; Hachamovitch, M.; Rubistein, A.; Kim, A. \& Goldstein, H. (1996). Inhibition of acute in vivo human immunodeficiency virus infection by human interleukin 10 treatment of SCID mice implanted with human fetal thymus and liver. Proceedings of the National Academy of Sciences USA, v.93, n.7, pp. 3126-3131, ISSN 0027-8424.

Koning, F.A.; Kwa, D.; Boeser-Nunnink, B.; Dekker, J.; Vingerhoed, J.; Hiemstra, H. \& Schuitemaker, H. (2003). Decreasing sensitivity to RANTES (regulated on activation, normally $\mathrm{T}$ cell-expressed and -secreted) neutralization of CC chemokine receptor 5-using, non-syncytium-inducing virus variants in the course of human immunodeficiency virus type 1 infection. The Journal of Infectious Diseases, v. 188, pp. 864-872, ISSN 0022-1899.

Kostrikis, L.G. ; Neumann, A.U. ; Thomson, B. ; Korber, B.T. ; McHardy, P. ; Karanicolas, R. ; Deustch, L. ; Lew, J.F. ; McIntoch, K. ; Pollack, H. ; Borkowsky, W. ; Spiegel, H.M. ; Palumbo, P. ; Oleske, J. ; Bardeguez, A. ; Luzuriaga, K. ; Sullivan, J. ; Wolinsky, S.M. ; Koup, R.A.; Ho, D.D. \& Moore, J.P. (1999). A polymorphism in the regulatory region of the CC-chemokine receptor 5 gene influences perinatal transmission of human immunodeficiency virus type 1 to African-American infants Journal of Virology, v. 73, n. 12, pp. 10264-10271, ISSN 0022-538X.

Kostrikis, L.G.; Huang, Y.; Moore, J.P.; Wolinsky, S.M.; Zhang, L.; Guo, Y.; Deutsch, L.; Phair, J.; Neumann, A.U.; Ho, D.D. (1998). A chemokine receptor CCR2 allele delays HIV-1 disease progression and is associated with a CCR5 promoter mutation. Nature Medicine, v. 4, n. 3, pp. 350-353, ISSN 1078-8956.

Kwa, D.; Boeser-Nunnink, B. \& Schuitemaker, H. (2003). Lack of evidence for an association between a polymorphism in CX3CR1 and the clinical course of HIV infection or virus phenotype evolution. AIDS, v. 17, n. 5, pp. 759-761, ISSN 0269-9370.

Ledergerber, B.; Egger, M.; Opravil, M.; Telenti, A.; Hirschel, B.; Battegay, M.; Vernazza, P.; Sudre, P.; Flepp, M.; Furrer, H.; Francioli, P. \& Weber, R. (1999). Clinical progression and virological failure on highly active antiretroviral therapy in HIV-1 patients: a prospective cohort study. Swiss HIV Cohort Study. The Lancet, v. 353, n.9156, pp. 863-868, ISSN 0099-5355.

Limou, S.; Coulonges, C.; Herbeck, J.T.; van Manen, D.; An, P.; Le Clerc, S.; Delaneau, O.; Diop, G.; Taing, L.; Montes, M.; van't Wout, A.B., Gottlieb, G.S.; Therwath, A.; Rouzioux, C.; Delfraissy, J.F.; Lelièvre, J.D.; LévyM Y,L HercbergM S,L DinaM C,L.; 
Phair, J.; Donfield, S.; Goedert, J.J.; Buchbinder, S.; EstaquierM J,L; Schächter, F.; Gut, I.; Froguel, P.; Mullins, J.I.; Schuitemaker, H.; Winkler, C. \& Zagury, J.F. (2010). Multiple-cohort genetic association study reveals CXCR6 as a new chemokine receptor involved in long-term nonprogression to AIDS. The Journal of Infectious Diseases, v. 202, n. 6, pp. 908-915, ISSN 0022-1899.

Liu, H.; Chao, D.; Nakayama, E.E.; Taguchi, H.; Goto, M.; Xin, X.; Takamatsu, J.K.; Saito, H.; Ishikawa, Y.; Akaza, T.; Juji, T.; Takebe, Y.; Ohishi, T.; Fukutake, K.; Maruyama, Y.; Yashiki, S.; Sonoda, S.; Nakamura, T.; Nagai, Y.; Iwamoto, A. \& Shioda, T. (1999). Polymorphism in RANTES chemokine promoter affects HIV-1 disease progression. Proceedings National Academy of Sciences USA, v. 96, n. 8, pp. 4581-4585, ISSN 00278424.

Liu, S-L.; Schacker, T.; Musey, L.; Shriner, D.; McElrath, M.J.; Corey, L. \& Mullins, J.I. (1997). Divergent patterns of progression to AIDS after infection from the same source: human immunodeficiency virus type 1 evolution and antiviral responses. Journal of Virology, v. 71, n. 6, pp. 4284-4295, ISSN 0022-538X.

Mabuka, J.M.; Mackelprang, R.D.; Lohman-Payne, B.; Majiwa, M.; Bosire, R.; John-Stewart, G.; Rowland-Jones, S.; Overbaugh, J. \& Farquhar, C. (2009). CCR2-64I polymorphism is associated with lower maternal HIV-1 viral load and reduced vertical HIV-1 transmission. Journal of Acquired Immune Deficiency Syndrome, v. 51, n. 2, pp. 235-237, ISSN 1525-4135.

Magierowska, M.; Theodorou, I.; Debré, P.; Sanson, F.; Autran, B.; Rivière, Y.; Charron, D.; French ALT and IMMUNOCO Study Groups \& Costagliola, D. (1999). Combined genotypes of CCR5, CCR2, SDF1, and HLA genes can predict the long-term nonprogressor status in human immunodeficiency virus-1-infected individuals. Blood, v. 93, n. 3, p. 936-941, ISSN 0006-4971.

Martin, M.P.; Dean, M.; Smith, M.W.; Winkler, C.; Gerrard, B.; Michael, N.L.; Lee, B.; Doms, R.W.; Margolick, J.; Buchbinder, S.; Goedert, J.J.; O’Brien, T.R.; Hilgartner, M.W.; Vlahov, D.; O'Brien, S.J. \& Carrington, M. (1998). Genetic acceleration of AIDS progression by a promoter variant of CCR5. Science, v. 282, n. 5395, pp. 1907-1911, ISSN 0036-8075.

McDermott, D.H.; Beecroft, M.J.; Kleeberger, C.A.; Al-Sharif, F.M.; Ollier, W.E.; Zimmerman, P.A.; Boatin, B.A.; Leitman, S.F.; Detels, R.; Hajeer, A.H. \& Murphy, P.M. (2000). Chemokine RANTES promoter polymorphism affects risk of both HIV infection and disease progression in the Multicenter AIDS Cohort Study. AIDS, v. 14, n. 17, pp. 2671-2678, ISSN 0269-9370.

McDermott, D.H.; Colla, J.S.; Kleeberger, C.A.; Plankey, M.; Rosenberg, P.S.; Smith, E.D.; Zimmerman, P.A.; Combadiere, C.; Leitman, S.F.; Kaslow, R.A.; Goedert, J.J.; Berger, E.A.; O'Brien, T.R. \& Murphy, P.M. (2000). Genetic polymorphism in CX3CR1 and risk of HIV disease. Science, v. 290, n.5499, pp. 2031, ISSN 0036-8075.

McDermott, D.H.; Zimmernan, P.A.; Guignard, F.; Kleeberger, C.A.; Leitman, S.F. \& Murphy, P.M. (1998). CCR5 promoter polymorphism and HIV-1 disease progression. Multicenter AIDS Cohort Study (MACS). The Lancet, v. 352, n.9131, pp.866-870, ISSN 0099-5355.

Meyer, L.; Magierowska, M.; Hubert, J-B.; Theodorou, I.; van Rij, R.; Prins, M.; de Roda, H.; Coutinho, R. \& Schuitemaker, H. (1999). CC-chemokine receptor variants, SDF-1 
polymorphism, and disease progression in 720 HIV-infected patients. AIDS, v. 13, n. 5, p. 624-626, ISSN 0269-9370.

Michael, N.L.; Louie, L.G.; Rohrbaugh, A.L.; Schultz, K.A.; Dayhoff, D.E.; Wang, C.E. \& Sheppard, H.W. (1997). The role of CCR5 and CCR2 polymorphisms in HIV-1 transmission and disease progression. Nature Medicine, v.3, n.10, pp.1160-1162, ISSN 1078-8956.

Modi, W.S.; Lautenberger, J.; An, P.; Scott, K.; Goedert, J.J.; Kirk, G.D.; Buchbinder, S.; Phair, J.; Donfield, S.; O'Brien, S.J. \& Winkler, C. (2006). Genetic variation in the CCL18CCL3-CCL4 chemokine gene cluster influences HIV type transmission and AIDS disease progression. American Journal of Human Genetics, v. 79, n.1, pp; 120-128, ISSN 1434-5161.

Mulherin, S.A.; O’Brien, T.R.; Ioannidis, J.P.A.; Goedert, J.J.; , Buchbinder, S.P.; Coutinho, R.A.; Jamieson, B.D.; Meyers, L.; Michael, N.L.; Pantaleo, G.; Rizzardi, G.P.; Schuitemaker, H.; Shepaard, H.W.; Theodorou, I.D.; Vlahov, D. \& Rosenberg, P.S. (2003). Effects of CCR5-Delta32 and CCR2-64I alleles on HIV-1 disease progression: the protection varies with duration of infection. AIDS, v. 17, n. 3, pp. 377-387, ISSN 0269-9370.

Mummidi, S.; Ahuja, S.S.; Gonzalez, E.; Anderson, S.A.; Santiago, E.N.; Stephan, K.T.; Craig, F.E.; O'Connell, P.; Tryon, V.; Clark, R.A.; Dolan, M.J. \& Ahuja, S.K. (1998). Genealogy of the CCR5 locus and chemokine system gene variants associated with altered rate if HIV-1 disease progression. Nature Medicine, v. 4, n.7, pp. 786-793, ISSN 1078-8956.

Naif, H.M.; Li, S.; Ho-Shon, M.; Mathijs, J.M.; Williamson, P. \& Cunningham, A.L. (1997). The state of maturation of monocytes into macrophages determines the effects of IL-4 and IL-13 on HIV replication. Journal of Immunology, v. 158, n. 1, pp. 501-511, ISSN 0016-5751.

Nakajima, T.; Kaur, G.; Mehra, N. \& Kimura, A. (2008). HIV-1/AIDS susceptibility and copy number variations in CCL3L1, a gene enconding a natural ligand for HIV-1 coreceptor CCR5. Cytogenetic and Genome Research, v.123, n.1-4, pp. 156-160, ISSN 1424-8581.

Nakajima, T.; Ohtani, H.; Naruse, T.; Shibata, H.; Mimaya, J.I.; Terunuma, H. \& Kimura, A. (2007). Copy number variations of CCL3L1 and long-term prognosis of HIV-1 infection in asymptomatic HIV-infected Japanese with hemophilia. Immunogenetics, v.59, n.10, pp. 793-798, ISSN 0093-7711.

Nguyen, L.; Li, M.; Chaowanachan, T.; Hu, D.J.; Vanichseni, S.; Mock, P.A.; van Griensven, F.; Martin, M.; Sangkum, U.; Choopanya, K.; Tappero, J.W.; Lal, R.B. \& Yang, C. (2004). CCR5 promoter haplotypes associated with HIV-1 discordant progression in Thai injection drug users. AIDS, v.18, n.9, pp.1327-1333, ISSN 0269-9370.

O' Brien, S.J.\& Moore, J.P. (2000). The effect of genetic variation in chemokines and their receptors on HIV transmission and progression to AIDS. Immunological Reviews, v. 177, pp. 99-111, ISSN 0105-2896.

O’ Brien, T.R.; McDermott, D.H.; Ioannidis, J.P.A.; Carrington, M.; Murphy, P.M.; Havlir, D.V. \& Richman, D.D. (2000). Effect of chemokine receptor gene polymorphisms on the response to potent antiretroviral therapy. AIDS, v. 14, n. 7, p. 821-826, ISSN 0269-9370. 
O’Brien, W.A.; Hartigan, P.M.; Daar, E.S.; Simberkoff, M.S. Hamilton, J.D. (1997). Changes in plasma HIV RNA levels and CD4+ lymphocyte counts predict both response to antiretroviral therapy and therapeutic failure. VA Cooperative Study Group on AIDS. Annals of Internal Medicine, v. 126, n.12, pp. 939-945, ISSN 0003-4819.

Pantaleo, G.; Demarest, J.F.; Schacker, T.; Vaccarezza, M.; Cohen, O.J.; Daucher, M.; Graziosi, C.; Schnittman, S.S.; Quinn, T.C.; Shaw, G.M.; Perrin, L.; Tambussi, G.; Lazzarin, A.; Sekaly, R.P.; Soudeyns, H.; Corey, L. \& Fauci, A.S. (1997). The qualitative nature of the primary immune response to HIV infection is a prognosticator of disease progression independent of the initial level of plasma viremia. Proceedings National Academy of Sciences USA, v. 94, n.1, pp. 254-258, ISSN 0027-8424.

Parczewski, M.; Leszczyszyn-Pynka, M.; Kaczmarczyk, M.; Adler, G.; Binczak-Kuleta, A.; Loniewska, B.; Boron-Kaczmarska, A. \& Ciechanowicz, A. (2009). Sequence variants of chemokine receptor genes and susceptibility to HIV-1 infection. Journal of Applied Genetics, v. 50, n. 2, pp. 159-166, ISSN 1234-1983.

Passam, A.M.; Sourvinos, G.; Krambovitis, E.; Miyakis, S.; Stavrianeas, N.; Zagoreos, I. \& Spandidos, D.A. (2007). Polymorphisms of CX(3)CR1 and CXCR6 receptors in relation to HAART therapy of HIV type 1 patients. AIDS Research and Human Retroviruses, v. 23, n. 8, pp.1026-1032, ISSN 0889-2229.

Passam, A.M.; Zafiropoulos, A.; Miyakis, S.; Zagoreos, I.; Stavrianeas, N.G.; Krambovitis, E. \& Spandidos, D.A. (2005). CCR2-64I and CXCL12 3'A alleles confer a favorable prognosis to AIDS patients undergoing HAART therapy. Journal of Clinical Virology, v. 34, pp. 302-309, ISSN 1386-6532.

Paxton, W.A.; Martin, S.R.; Tse, D.; O’Brien, T.R.; Skurnick, J.; VanDevanter, N.; Padian, N.; Braun, J.F.; Kotler, D.P.; Wolinsky, S.M. \& Koup RA. (1996). Relative resistance to HIV-1 infection of CD4 lymphocytes from persons who remain uninfected despite multiple high-risk sexual exposure. Nature Medicine, v.2, n.4, pp. 412-417, ISSN 1078-8956.

Petit, S.J.; Chayen, N.E. \& Pease, J.E.(2008). Site-directed mutagenesis of the chemokine receptor CXCR6 suggests a novel paradigm for interactions with the ligand CXCL16. European Journal of Immunology, v. 38, n. 8, pp. 2337-2350.

Piacentini, L., Biasin, M., Fenizia, C. \& Clerici, M. (2009). Genetic correlates of protection against HIV infection: the ally within. Journal of Internal Medicine, v. 265, pp. 110124, ISSN 0954-6820.

Potter, S. J., Lacabaratz, C., Lambotte, O., Perez-Patrigeon, S., Vingert, B., Sinet, M., Colle, J. H., Urrutia, A., Scott-Algara, D.; Boufassa, F.; Delfraissy, J.F.; Thèze, J.; Venet, A. \& Chakrabarti, L.A. (2007). Preserved central memory and activated effector memory CD4 ${ }^{+}$T-cell subsets in human immunodeficiency virus controllers: an ANRS EP36 study. Journal of Virology, v. 81, n.24, pp. 13904-13915, ISSN 0022-538X

Puissant, B.; Roubinet, F.; Massip, P.; Sandres-Saune, K.; Apoil, P-A.; Abbal, M.; Pasquier, C.; Izopet, J. \& Blancher, A. (2006). Analysis of CCR5, CCR2, CX3CR1, and SDF1 polymorphisms in HIV-positive treated patients: impact on response to HAART and o peripheral T lymphocyte counts. AIDS Research and Human Retroviruses, v. 22, n. 2, pp. 153-162, ISSN 0889-2229.

Qian, Y.; Sun, H.; Lin, K.; Shi, L.; Shi, L. \& Chu, J. (2008). Distribution of CCR5-Delta32, CCR2-64I, SDF1-3'A, CX3CR1-249I, and CX3CR1-280M in Chinese populations. AIDS Research Human Retroviruses, v. 24, n. 11, pp. 1391-1397. 
Quillent, C.; Oberlin, E.; Braun, J.; Rousset, D.; Gonzales-Canali, G.; Métais, P.; Montagnier, L.; Virelizier, J-L.; Arenzana-Seisdedos, F. \& Beretta, A. (1998). HIV-1 resistance phenotype conferred by combination of two separate inherited mutations of CCR5 gene. The Lancet, v. 351, pp. 14-18, ISSN 0099-5355.

Ramana, G.V.; Vasanthi, A.; Khaja, M.; Su, B.; Govindaiah, V.; Jin, L.; Singh, L. \& Chakraborty, R. (2001). Distribution of HIV-1 resistance-conferring polymorphic alleles SDF-1-3'A, CCR2-64I and CCR5-Delta32 in diverse populations of Andhra Pradesh, South India. Journal of Genetics, v. 80, n.3, pp. 137-140.

Rathore, A.; Chatterjee, A.; Sivarama, P.; Yamamoto, N.; Singhal, P.K. \& Dhole, T.N. (2009). Association of CCR5-59020 A/G and CCL3L1 copy number polymorphism with HIV type 1 transmission/progression among HIV type 1-seropositive and repeatedly sexually exposed HIV type 1-seronegative North Indians. AIDS Research and Human Retroviruses, v.25, n.11, pp.1149-1156, ISSN 0889-2229.

Reiche, E. M.; Ehara Watanabe, M.A.; Bonametti, A. M.; Kaminami Morimoto, H.; Akira Morimoto, A.; Wiechmann, S.L.; Breganó, J.W.; Matsuo, T.; Vissoci Reiche, F.; Miranda, H.C.; Brajão Oliveira, K.; Vogler, I.H.; Siscar, A.R. (2006). The effect of stromal cell-derived factor 1 (SDF1/CXCL12) genetic polymorphism on HIV-1 disease progression. International Journal of Molecular Medicine, v. 18, n.4, pp. 785793, ISSN 1107-3756.

Reiche, E.M.V.; Bonametti, A.M.; Voltarelli, J.C.; Morimoto, H.K. \& Watanabe, M.A.E. (2007). Genetic polymorphisms in the chemokine and chemokine receptors: impact on clinical course and therapy of the human immunodeficiency virus type 1 infection (HIV-1). Current Medicinal Chemistry, v.14, n. 12, pp. 1325-1334, ISSN 0929-8673.

Reynes, J.; Portales, P.; Segondy, M.; Baillat, V.; André, P.; Réant, B.; Avinens, O.; Couderc, G.; Benkirane, M.; Clot, J.; Eliaou, J.F. \& Corbeau, P. (2000). CD4+ T cell surface CCR5 density as a determining factor of virus load in persons infected with human immunodeficiency virus type 1. The Journal of Infectious Diseases, v. 181, n.3, pp. 927932, ISSN 0022-1899.

Rigato, P.O.; Hong, M.A.; Casseb, J.; Ueda, M.; de Castro, I.; Benard, G. \& Duarte, A.J. (2008). Better CD4+ $\mathrm{T}$ cell recovery in Brazilian HIV-infected individuals under HAART due to cumulative carriage of SDF-1-3'A, CCR2-V64I, CCR5- 32 and CCR5promoter 59029A/G polymorphisms. Current HIV Research, v. 6, n. 5, pp. 466-473, ISSN 1570-162X.

Risma, K.A.; Wang, N.; Andrews, R.P.; Cunningham, C.M.; Ericksen, M.B.; Bernstein, J.A.; Chakraborty, R \& Hershey, G.K. (2002). V75R567 Il-4 receptor alpha is associated with allergic asthma and enhanced IL-4 receptor function. Journal of Immunology, v.169, n.3, pp. 1604-1610, ISSN 0016-5751.

Rosenberg, Z.F. \& Fauci, A.S. (1991). Immunopathogenesis of HIV infection. FASEB Journal, v. 5, pp. 2382-2390.

Salem, A.H.; Farid, E.; Fadel, R.; Abu-Hijleh, M.; Almawi, W.; Han, K.; Batzer, M.A. (2009). Distribution of four HIV type 1-resistance polymorphisms (CCR5-Delta32, CCR5m303, CCR2-64I, and SDF1-3'A) in the Bahraini population. AIDS Res Hum Retroviruses, v. 25, n.10, pp 973-977.

Samsom, M.; Libert, F.; Doranz, B.J.; Rucker, J.; Liesnard, C.; Farber, C.M.; Saragosti, S.; Lapoumeroulie, C.; Cognaux, J.; Forceille, C.; Muyldermans, G.; Verhofstede, C.; Burtonboy, G.; Georges, M.; Imai, T.; Rana, S.; Yi, Y.; Smyth, R.J.; Collman, R.G.; 
Doms, R.W.; Vassart, G. \& Parmentier, M. (1996). Resistance to HIV-1 infection in Caucasian individuals bearing mutant alleles of the CCR-5 chemokine receptor gene. Nature, v. 382, n. 6593, pp. 722-726, ISSN 0028-0836.

Schuitemaker, H.; Koot, M.; Kootstra, N.A.; Dercksen, M.W.; de Goede, R.E.Y.; van Steenwijk, R.P.; Lange, J.M.; Schattenkerk, J.K.M.; Miedema, F. \& Tersmette, M. (1992). Biological phenotype of human immunodeficiency virus type 1 clones at different stages of infection: progression of disease is associated with a shift from monocytotropic to T-cell-tropic virus populations. Journal of Virology, n. 66, n.3, pp. 1354-1360, ISSN 0022-538X.

Smith, M.W.; Carrington, M.; Winkler, C.; Lomb, D.; Dean, M.; Huttley, G. \& O’Brien, S.J. (1997). CCR2 chemokine receptor and AIDS progression. Nature Medicine, v.3, pp. 1052-1053, ISSN 1078-8956.

Smith, M.W.; Dean, M.; Carrington, M.; Winkler, C.; Huttley, G.A.; Lomb, D.A.; Goedert, J.J.; O’Brien, T.R.; Jacobson, L.P.; Kaslow, R.; Buchbinder, S.; Vittinghoff, E.; Vlahov, D.; Hoots, K.; Hilgartner, M.W. \& O'Brien, S.J. (1997). Contrasting genetic influence of CCR2 and CCR5 variants on HIV-1 infection and disease progression. Hemophilia Growth and Development Study (HGDS), Multicenter AIDS Cohort Study (MACS), Multicenter Hemophilia Cohort Study (MHCS), San Francisco City Cohort (SFCC), ALIVE Study. Science, v. 277, pp. 959-965, ISSN 0036-8075.

Soriano, A.; Lozano, F.; Oliva, H.; Garcia, F.; Nomdedeu, M.; De Lazzari, E.; Rodríguez, C.; Barrasa, A.; Lorenzo, J.I.; Del Romero, J.; Plana, M.; Miró, J.M.; Gatell, J.M.; Vives, J. \& Gallart, T. (2005). Polymorphisms in the interleukin-4 receptor alpha chain gene influence susceptibility to HIV-1 infection and its progression to AIDS. Immunogenetics, v.57, n.9, pp.644-654, ISSN 0093-7711.

Soriano, A.; Martínez, C.; García, F.; Plana, M.; Palou, E.; Lejeune, M.; Aróstegui, J.I.; De Lazzari, E.; Rodriguez, C.; Barrasa, A.; Lorenzo, J.I.; Alcamí, J.; Romero, J.D.; Miró, J.M.; Gatell, J.M. \& Gallart, T. (2002). Plasma stromal cell-derived factor (SDF)-1 levels, SDF1-3'A genotype, and expression of CXCR4 on T lymphocytes: their impact on resistance to in human immunodeficiency virus type 1 infection and its progression. The Journal of Infectious Diseases, v. 186, n. 7, pp. 922-931, ISSN 00221899.

Su, B.; Jin, L.; Hu, F.; Xiao, J.; Luo, J.; Lu, D.; Zhang, W.; Chu, J.; Du, R.; Geng, Z.; Qiu, X.; Xue, J.; Tan, J.; O'Brien, S.J. \& Chakraborty, R. (1999). Distribution of two HIV-1 resistant polymorphisms (SDF1-3'A and CCR2-64I) in East Asia and world populations and its implication in AIDS epidemiology. American Journal of Human Genetics, v. 65, n. 4, pp. 1047-1053, ISSN 1434-5161.

Su, Q.; Mai, Z.; Zang, N.; Wu, S.; Xiao, X. \& Liang, H. (2010). Distribution of CCR5-delta-32, CCR2-64I, and SDF1-3'A in Guangxi Zhuang population. Journal of the International Association of Physicians in AIDS Care, v. 9, n. 3, pp. 145-149.

Tan, X.H.; Zhang, J.Y.; Di, C.H.; Hu, A.R.; Yang, L.; Qu, S.; Zhao, R.L.; Yang, P.R. \& Guo, S.X. (2009). Distribution of CCR5-Delta32, CCR5m303A, CCR2-64I and SDF1-3'A in HIV-1 infected and uninfected high-risk Uighurs in Xinjiang, China. Infection, Genetics and Evolution, v. 10, n. 2, pp. 268-272.

Theodorou, I.; Meyer, L.; Magierowska, M.; Katlama, C. \& Rouzioux, C. (1997). HIV-1 infection in an individual homozygous for CCR5 delta 32. Seroco Study Group. The Lancet, v. 349, n.9060, pp. 1219-1220, ISSN 0099-5355. 
Tresoldi, E.; Romiti, M.L.; Boniotto, M.; Crovella, S.; Salvatori, F.; Palomba, E.; Pastore, A.; Cancrini, C.; Martino, M.; Plebani, A.; Castelli, G.; Rossi, P.; Tovo, P.A.; Amoroso, A.; \& Scarlatti, G. in Cooperation with the European Shared Cost Project Group and the Italian Register for GIV Infection in Children. (2002). Prognostic value of the stromal cell-derived factor $13^{\prime} \mathrm{A}$ mutation in pediatric human immunodeficiency virus type 1 infection. The Journal of Infectious Diseases, v. 185, pp. 696-700, ISSN 0022-1899.

Vaamonde, C.M.; Hoover, D.R.; Anastos, K.; Tan, T.; Shi, Q.; Gao, W.; Kovacs, A.; Cohen, M.; De Hovitz J. \& Glesby, M.J. (2006). Factors associated with poor immunologic response to virologic suppression by highly active antiretroviral therapy in HIVinfected women. AIDS Research and Human Retroviruses, v. 22, n.3, pp. 222-231, ISSN 0889-2229.

van Rij, R.P.; Broersen, S.; Goudsmit, J.; Coutinho, R.A. \& Schuitemaker, H. (1998). The role of a stromal cell-derived factor- 1 chemokine gene variant in the clinical course of HIV-1 infection. AIDS, v. 12, n. 9, pp. F-85-F90, ISSN 0269-9370.

Vasilescu, A.; Terashima, Y.; Enbomoto, M.; Heath, S.; Poonpiriya, V.; Gatanaga, H.; Do, H.; Diop, G.; Hirtzig, T.; Auewarakul, P.; Lauhakirti, D.; Sura, T.; Charneau, P.; Marullo, S.; Therwath, A.; Oka, S.; Kanegasaki, S.; Lathrop, M.; Matsushima, K.; Zagury, J.F. \& Matsuda, F. (2007). A haplotype of the human CXCR1 gene protective against rapid disease progression in HIV-1+ patients. Proceedings of the National Academy of Sciences USA, v. 104, n.9, pp. 3354-3359, ISSN 0027-8424.

Veloso, S.; Olona, M.; García, F.; Domingo, P.; Alonso-Villaverde, C.; Broch, M.; Peraire, J.; Viladés, C.; Plana, M.; Pedrol, E.; López-Dupla, M.; Aguilar, C.; Gutiérrez, M.; Leon, A.; Tasias, M.; Gatell, J.M.; Richart, C. \& Vidal, F. (2010). Effect of TNF- $\alpha$ genetic variants and CCR5- $\triangle 32$ on the vulnerability to HIV-1 infections and disease progression in Caucasian Spaniards. BMC Medical Genetics, v.11, pp.63, ISSN 14712350.

Verma, R.; Guptya, R.B.; Singh, K.; Bhasin, R.; Shukla, A.A.; Chauhan, S.S. \& Luthra, K. (2007). Distribution of CR5 332, CCR2-64I and SDF1-3'A and plasma levels of SDF-1 in HIV-1 seronegative North Indians. Journal of Clinical Virology, v. 38, pp. 198-203, ISSN 1386-6532.

Viard, J.P.; Mocroft, A.; Chiesi, A.; Kirk, O.; Roge, B.; Panos, G.; Vetter, N.; Bruun , J.N.; Jonson, M. \& Lundgren, J.D.(2001) Influence of age on CD4 cell recovery in human immunodeficiency virus-infected patients receiving highly active antiretroviral therapy: evidence from the Euro SIDA study. The Journal of Infectious Diseases, v. 183 n.8, pp. 1290-1294, ISSN 0022-1899.

Vidal, F., Peraire, J., Domingo, P., Broch, M., Knobel, H., Pedrol, E., Dalmau, D., Vilades, C. \& Sambeat, MA. (2005a). Lack of association of SDF-1 3'A variant allele with longterm nonprogressive HIV-1 infection is extended beyond 16 years. Journal of Acquired Immune Deficiency Syndrome, v. 40, pp. 276-279, ISSN 1525-4135.

Vidal, F., Vilades, C., Domingo, P., Broch, M., Pedrol, E., Dalmau, D., Knobel, H., Peraire, J., Gutierrez, C.; Sambeat, M.A.; Fontanet, A.; Deig, E.; Cairó, M.; Montero, M.; Richart, C.; Mallal, S. \& Chemokines LTNP Study Group. (2005b). Spanish HIV-1infected long-term nonprogressors of more than 15 years have an increased frequency of the CX3CR1 249I variant allele. Journal of Acquired Immune Deficiency Syndrome, v. 40, n.5, pp. 527-531, ISSN 1525-4135. 
Wang, F-S.; Hong, W-G.; Cao, Y.; Liu, M-X.; Jin, L.; Hu, L-P.; Wang, Z.; Feng, T-J.; Hou, J.; Zhang, B.; Shi, M.; Xu, D-P.; Lei, Z-Y.; Wang, B.; Liu, Z-D.; Ye, J-J.; Peng, L.; Qiu, Y. \& Winkler, C. (2003). Population survey of CCR5- $\triangle 32$, CCR m3030, CCR2b 64I, and SDF1 3'A allele frequencies in indigenous Chinese healthy individuals, and HIV-1 infected and HIV-1-unifected individuals in HIV-1 risk groups. Journal of Acquired Immune Deficiency Syndrome, v. 32, n. 2, pp. 124-130, ISSN 1525-4135.

Wichukchinda, N., Nakayama, E. E., Rojanawiwat, A., Pathipvanich, P., Auwanit, W., Vongsheree, S., Ariyoshi, K., Sawanpanyalert, P. \& Shioda, T. (2006). Protective effects of IL4-589T and RANTES-28G on HIV-1 disease progression in infected Thai females. AIDS, v. 20, pp.189-196, ISSN 0269-9370.

Williamson, C.; Loubser, S.A.; Brice, B.; Joubert, G.; Smit, T.; Thomas, R.; Visagie , M.; Cooper M, Ryst E van der. (2000). Allelic frequencies of host genetic variants influencing susceptibility to HIV-1 infection and disease in South African populations. AIDS, v. 14, n. 4, p. 449-451, ISSN 0269-9370.

Winkler, C.; Modi, W.; Smith, M.W.; Nelson, G.W.; Wu, X.; Carrington, M.; Dean, M.; Honjo, T.; Tashiro, K.; Yabe, D.; Buchbinder, S.; Vittinghoff, E.; Goedert, J.J.; O’Brien, T.R.; Jacobson, L.P.; Detels, R. Donfield, S.; Willoughby, A.; Gomperts, E.; Vlahov, D.; Phair, J. \& O'Brien, S.J. (1998). Genetic restriction of AIDS pathogenesis by an SDF-1 chemokine gene variant. ALIVE study, Hemophilia Growth and Development Study (HGDS), Multicenter AIDS Cohort Study (MACS), Multicenter Hemophilia Cohort Study (MHCS), San Francisco City Cohort (SFCS). Science, v. 279, n. 5349, pp. 389-393, ISSN 0036-8075.

Wit, F.W.; van Rij. R.P.; Weverling, G.J.; Jange, J.M. \& Schuitemaker, H. (2002). CC chemokine receptor 5 delta32 and CC chemokine receptor 2 64I polymorphisms do not influence the virologic and immunologic response to antiretroviral combination therapy in human immunodeficiency virus type 1-infected patients. The Journal of Infectious Diseases, v. 186, n.12, pp. 1726-1732, ISSN 0022-1899.

Yamashita, T.E.;, Phair, J.P.; Muñoz, A.; Margolick, J.B.; Detels, R.; O’Brien, S.J.; Mellors, J.W.; Wolinsky, S.M. \& Jacobson, L.P. (2001). Immunologic and virologic response to highly active antiretroviral therapy in the Multicenter AIDS Cohort Study. AIDS, v. 15, p. 735-746, ISSN 0269-9370.

Zimmerman, P.; Buckler-White, A.; Alkhatib, G.; Spalding, T.; Kubofcik, J.; Combadiere, C.; Weissman, D.; Cohen, O.; Rubbert, A.; Lam, G.; Vaccarezza, M.; Kennedy, P.E.; Kumaraswami, V.; Giorgi, J.V.; Detels, R.; Hunter, J.; Choper, M.; Berger, E.A.; Fauci, A.S.; Nutman, T.B. \& Murphy, P.M. (1997). Inherited resistance to HIV-1 conferred by an inactivating mutation in CC chemokine receptor 5: studies in populations with contrasting clinical phenotypes, defined racial background, and quantified risk. Molecular Medicine, v. 3, n. 1, pp. 23-26, ISSN 1077-1551. 


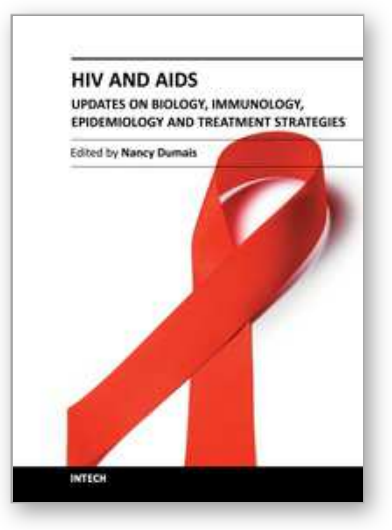

\section{HIV and AIDS - Updates on Biology, Immunology, Epidemiology and Treatment Strategies}

Edited by Dr. Nancy Dumais

ISBN 978-953-307-665-2

Hard cover, 694 pages

Publisher InTech

Published online 26, October, 2011

Published in print edition October, 2011

The continuing AIDS pandemic reminds us that despite the unrelenting quest for knowledge since the early 1980s, we have much to learn about HIV and AIDS. This terrible syndrome represents one of the greatest challenges for science and medicine. The purpose of this book is to aid clinicians, provide a source of inspiration for researchers, and serve as a guide for graduate students in their continued search for a cure of HIV. The first part of this book, â€œFrom the laboratory to the clinic,â€ and the second part, â€œFrom the clinic to the patients,â€ represent the unique but intertwined mission of this work: to provide basic and clinical knowledge on HIV/AIDS.

\section{How to reference}

In order to correctly reference this scholarly work, feel free to copy and paste the following:

Edna Maria Vissoci Reiche, Marla Karine Amarante and Maria Angelica Ehara Watanabe (2011). The Role of Genetic Polymorphisms in the Chemokine and their Receptors and Cytokines in the Human Immunodeficiency Virus Type 1 (HIV-1) Infection, HIV and AIDS - Updates on Biology, Immunology, Epidemiology and Treatment Strategies, Dr. Nancy Dumais (Ed.), ISBN: 978-953-307-665-2, InTech, Available from:

http://www.intechopen.com/books/hiv-and-aids-updates-on-biology-immunology-epidemiology-and-treatmentstrategies/the-role-of-genetic-polymorphisms-in-the-chemokine-and-their-receptors-and-cytokines-in-thehuman-im

\section{INTECH}

open science | open minds

\author{
InTech Europe \\ University Campus STeP Ri \\ Slavka Krautzeka 83/A \\ 51000 Rijeka, Croatia \\ Phone: +385 (51) 770447 \\ Fax: +385 (51) 686166 \\ www.intechopen.com
}

\author{
InTech China \\ Unit 405, Office Block, Hotel Equatorial Shanghai \\ No.65, Yan An Road (West), Shanghai, 200040, China \\ 中国上海市延安西路65号上海国际贵都大饭店办公楼 405 单元 \\ Phone: +86-21-62489820 \\ Fax: $+86-21-62489821$
}


(C) 2011 The Author(s). Licensee IntechOpen. This is an open access article distributed under the terms of the Creative Commons Attribution 3.0 License, which permits unrestricted use, distribution, and reproduction in any medium, provided the original work is properly cited. 